\title{
OSUD, DÍLO V MNOHÉM ZLOMOVÉ
}

Historie opery Osud začíná rokem 1903, který byl v Janáčkově životě jedním z nejtěžších. V únoru 1903 zemřela jeho dcera Olga následkem dlouholeté srdeční choroby a těžké virózy, kterou se nakazila při návštěvě skladatelova bratra Františka v Petrohradu. Janáček tak přišel o svého nejbližšího a nejdražšího člověka. Přes velmi špatný psychický stav dokončil operu Jeji pastorkyňa a nabídl ji k provedení pražskému Národnímu divadlu. Odpověd’ ředitele Gustava Schmoranze přišla 28. dubna 1903: „Jest mi upř́mně lito, že operu Vaši nemůžeme prijimouti k provozování. Př́lit’ bychom si, aby dílo Vaše potkalo se na jevišti s plným úspěchem pro nás i pro Vás, obáváme se však, že by dílo Vaše úspěchu takového nemélo. Partituru i klavírni výtah Vám vracíme." "1 To byla pro Janáčka další zničující rána. Manželka Zdeňka vzpomíná, že upadl do hluboké deprese a pocitu vlastní tvůrčí nemohoucnosti.

\section{Intermezzo - Andělská sonata}

Tato situace však skladatele paradoxně vyburcovala k další tvůrčí práci. Zřejmě v tomto nelehkém období si přečetl román Josefa Merhauta Andělská sonata. Př́běh románu, se silně morálním podtextem, je v podstatě jednoduchý.

Mladý inženýr Hřivna žije v Brně s půvabnou manželkou Anežkou. Do jejich vztahu se začne vkrádat nuda. Na vině je především skutečnost, že manželství zůstává bezdětné. Hřivna řeší svou citovou deprivaci různými koníčky, především fotografováním. Jednou při focení vilky v okolí Brna pořídí i snímek její obyvatelky, bohaté Němky, se kterou začne udržovat poměr. Ačkoliv mu vztah nic nepřináší, přece je stále $\mathrm{k}$ milence přitahován. Jeho cizoložství začne tušit manželka a její žárlivost vede k zoufalému činu. Když Hřivna spí, odcizí mu klíče a vloupá se do jeho stolu. Tam najde milenčiny dopisy plné intimností

1 Dopis je uložen v JA MZM, sign. D 1205. Viz též: TYRELL, John. Janáček’s Operas. A Documentary account. London: Faber and Faber, 1992. JP 15. 
[Janáček neměl tušení, že přesně totéž se stane o půl roku později i jemu]. Anežka manželovi vše vyčte a ve vztahu dojde k naprostému odcizení. Hřivna pocit’uje vinu, ale i Anežka dochází po čase k přesvědčení, že se provinila. V mládí byla velmi zbožná a Boha vyměnila za manžela, který se stal jejím novým smyslem života. Když prosí Pannu Marii o pomoc, je jí vnuknuta myšlenka, aby učinila pout' na Sv. Hostýn. To také řekne Hřivnovi, který se na pout' vydá s ní. Na Hostýně po prosbě k Orodovnici prožijí novou, očištěnou „,svatební noc". V dalších měsících se vztah manželů zlepší, ale Hřivna stále sleduje na Anežce smutek i fyzické strádání. Bojí se, že jí svým nezodpovědným chováním způsobil zdravotní problémy. Ve skutečnosti je však jeho manželka těhotná a devět měsíců po hostýnské noci se narodí vytoužený syn. Anežka je však slabá a přichází krátce po porodu o mateřské mléko. Hřivna rychle najde vhodnou kojnou a slabé dítě zachrání. Jeho život začíná mít opět smysl, věnuje se dítěti, začíná být citlivý k sociálním nespravedlnostem ve společnosti, zabývá se svým vztahem $\mathrm{k}$ víře. Jednou ve slabé chvíli Hřivna málem podlehne svodům sousedky, ale $\mathrm{v}$ poslední chvíli si vzpomene na následky svého předchozího prohřešku a od sousedky se odvrací. Za čas manžele potká strašlivá rána - jejich chlapeček náhle umírá. Propadnou v naprostou beznaděj, krátce na to se však chlapec oběma zjeví ve spánku, takže manželé se těší tím, že dítě nadále zůstává s nimi. Jejich víra jim pomáhá žít dále.

Vzhledem ke skladatelově nelehké životní situaci není výběr látky překvapivý, jelikož i manželé Janáčkovi museli po ztrátě druhého dítěte hledat sílu k dalšímu společnému životu. Janáček již 11. května 1903 požádal autora knihy o schůzku. Merhaut s potěšením přijal a vyzval Janáčka ke společné odpolední procházce. $^{2}$ Nedlouho poté, 4. června 1903, Merhaut Janáčkovi napsal, že je potěšen skladatelovým zájmem o Andělskou sonatu, ale upozorňuje na př́lišnou lyričnost a nedějovost textu, která by opernímu libretu neprospívala. Rozhodnutí však ponechal na Janáčkovi s tím, že úpravu románu na dramatický text by sám nerad prováděl. Doporučuje pro tento úkol oslovit Dominika Pavlíčka, redaktora Lidových novin. Nicméně spolupráce na libretu se nezříká a v závěru dodává: „Bud'te ujištěn, že láska, kterou Jste zahořel jako geniální hudebník a jemně cítici kritik k mé látce, mne velice oblažuje a ctí, a že učiním vše, abyste byl s výsledkem společné naši práce spokojen. “3

To, že byl Janáčkủv zájem o Andělskou sonatu skutečně vážný, naznačuje i skutečnost, že se 30. května 1903 sám vydal na pout' na sv. Hostýn, kde se děj románu zčásti odehrává (Janáček Hostýn určil za dějišsě 3. jednání). ${ }^{4}$ Aby co nejlépe prožil atmosféru pouti, zůstal s poutníky v noci v kostele. Tuto zkušenost velmi detailně zaznamenal do svého zápisníku:

\footnotetext{
2 Dopis je uložen v JA MZM, B 755.

3 Dopis je uložen v JA MZM, B 768.

4 Zápisníky jsou uloženy v JA MZM, sign. Z 25 (lístek), Z 26 (s. 85-86).
} 
„Noc v kostele! To jsem neviděl jaktěživ! Dívám se od oltáre. Do dveři od kostela vyhliži nebe, měsic temni se čím dále tím vic. Tajuplně zdvíhaji se ve tmě stěny se svatými. Kůr s varhany. Svičky drži si skupina lidu hned u vchodu, nalevo, dále druhá, třetí, zpivá Kde domov můj, nápěv zahučaly hory [notový záznam] u oltáře dvě takové skupiny. U mne na pravo již leži lidé na zemi a spěji. Přeběhne děvče zprava a jde rozsvítit si svičku, za chvili i na levo skupina se rozezvučí. Za chvili spojí se sta lidí různými nápěvy v tonině F. Prostředkem projdou billé Slováčky; mezitím kolem nakukávaji do obličeje: hledaji svoje lidi. S dřevěnou nohou uprostřed cupe, padne na tvár̆! Studenti kloni se ku Oltári hlavnímu. Kloní se $k$ vedlejšimu, kde tak pěkně zpivali! Jako socha uprostřed kostela kleči děvče již dlouho. Jest 10 hod. a tak to bude do rána. Těm se zjev, o Maria! To jest obraz, který člověk chce prožit! [...] Ty valašky billé - jak se udiveně divaly. Cizi umělec - noc - ráno - vycházi slunko, osvětluje kraj, jako zjeveni Panny Marie. [...] Dojem uchvacujici. "5

Na tento silný duchovní zážitek, který skladatel jistě vnímal obzvláśs' citlivě vzhledem k nedávné ztrátě dcery, vzpomíná Janáček i o dvacet let později, i když poněkud lakoničtěji: „Putoval jsem na Hostýn, nocoval tam, dokousán hmyzem, bouři zažil, poutniky ospalé ve tmě pošlapal. “6

Merhautova neochota přepracovat román na operní libreto vedla k odsunu práce až na čas po letních prázdninách. Avšak „osud“ tomu chtěl, že se Janáček k látce Andělské sonaty již nikdy nevrátil.

\section{Janáčkovo osudové setkání}

Letní prázdniny roku 1903 se ubíraly v podstatě obvyklým způsobem. V červenci Janáček pobýval na rodných Hukvaldech, kde tentokrát cíleně zapisoval nápěvky Lidky a Vincka, dětí Vincence Sládka, v jehož domě bydlel. Dětské nápěvky si Janáček ve Sládkově rodině zaznamenával několik let a dokládal na mluveném projevu mentální vývoj dětí (vše nakonec zúročil ve studii Nápěvky dětské mluvy). Po krátkém pobytu v Brně se 15. srpna vydal vlakem do Luhačovic. Lázně Janáček navštěvoval pravidelně, ale do Luhačovic přijel po mnohaleté odmlce, aby se zde stal v následujících letech pravidelným hostem. Ubytoval se v „Lázeňském hotelu“ a od začátku pozorně sledoval lázeňský ruch; zapisoval si nápěvky hostů i personálu, zaznamenal také kolonádní orchestr i hudeckou kapelu. Mezi množstvím nápěvků se objevil také záznam mluvy paní Kamily Urválkové, osmadvacetileté krásky, manželky lesního správce v Zahájí u Dolních Kralovic. Janáčkova chot' Zdeňka ve svých memoárech vzpomíná: „Zanedlouho dostala jsem od něho dopis, v němž mi sděloval, že našel anděla, takového, jako byl ten, co jsme jej pochovali. A že má také srdeční vadu. Myslela jsem, že jde

5 Zápisník je uložen JA MZM, Z 28 (s. 39-55).

6 JANÁČEK, Leoš. Pohled do života i dila. Uspořádal a vydal Adolf Veselý. Praha: František Borový, 1924, s. 96. 
o nějakou dívčinu a dle toho jsem také mužovi odpovéděla. Ale když se po prázdninách vrátil a začal mi o tom andělu vypravovat, ukázalo se, že je to mladá a krásná pani Kamila Urválková, chot fortta z Dolnich Královic. Nemohla prý snést, když viděla muže v Luhačovicích tak smutného a osamélého. Poslala mu k jeho stolu kytici rudých růži. Pak se seznámili."“7

Mladá půvabná žena Janáčkovi při četných schůzkách vyprávěla svůj milostný př́běh z mládí, který skladatele zaujal. Kamila Urválková, dívčím jménem Schillerová (po nevlastním otci Houdková), byla dcerou bohatého majitele pekařské živnosti v Hybernské ulici v Praze, který mimo jiné vlastnil vilu v Dobřichovicích, kde rodina žila. Její bratr byl básník Egon Schiller. Jako mladé děvče se zamilovala do skladatele a dirigenta Ludvíka Vítězslava Čelanského. O jejich vztahu nemáme žádný přímý doklad, ale pravdou je, že Čelanský po rozchodu zkomponoval na vlastní libreto operu Kamilla. Opera byla úspěšně provedena na scéně pražského Národního divadla v roce 1897, týž rok vyšlo libreto tiskem. Děj opery je více než prostinký:

Mladý básník Viktor Znělský je zamilován do slečny Kamily, sestry svého př́tele Jaroslava. Ten zná př́itelovu nesmělost a všemožně jej povzbuzuje. Ovšem o krásnou Kamilu projevuje zájem i jistý důstojník - velkostatkář Novák. Viktor Kamile při návštěvě v rodinné vile za Prahou vyjeví svou lásku a ona ji opětuje. Ač je ochotna jít s mladým básníkem na konec světa, za krátký čas je Viktor v divadle svědkem, jak se velkostatkáŕ Novák k jeho milované Kamile chová velmi důvěrně. To jej rozlítí a Nováka urazí. Během této scény však Kamila zamlčí svou náklonnost k Viktorovi a dokonce podnícena svou výchovou se na chudého básníka oboří a svým snoubencem prohlašuje bohatého Nováka. Později však vyjde najevo, že ten po celou dobu, kdy se dvořil Kamile, udržoval poměr se svou komornou. Jaroslav Nováka vyžene a vyčiní sestře za její lehkomyslné chování. Kamila se pokusí Viktora poprosit za odpuštění, ale ten odchází se slovy: „Vy jste mne, slečno, neměla nikdy ráda!“

Čelanský libreto doplňuje také o charakteristiku postav, kde Kamilu představuje jako, „[...] dosud neuzrálý a proto neurčený charakter. Její skutky jsou výsledkem dvou vlivư: jeji duše a jejího okolí. Vždycky zvitězi duše, mluví-li s člověkem duševně cenným - a vždy zvítězi okolí, objevi-li se člověk její společenské vrstvy. Kamille bylo nutno projiti něčim, kde by se našla. "8 Písemný pramen, který by jednoznačně dokazoval, že Čelanský operu zamýšlel jako pomstu Kamile Urválkové, pochopitelně nemáme, ale pravdou je, že některé reálie odpovídají skutečnosti (rodinná vila za Prahou, bratr Kamily atp.). Na tuto spojitost upozornila v roce 1956 badatelka Theodora Straková a záhy také Jaroslav Vogel.

7

TRKANOVÁ, Marie. Paměti: Zdeňka Janáčková - můj život. Brno: Nakladatelství Šimon Ryšavý, 1998, s. 78.

8 ČELANSKÝ, Ludvík Vítězslav. Kamilla. Praha: Fr. A. Urbánek, 1897, s. [7]. 
V každém př́ípadě př́běh, který Janáčkovi vyprávěla Kamila Urválková, skladatele natolik zaujal, že se rozhodl, se sobě vlastním cítěním s neštastnými ženami, napravit nelichotivý obraz nevinné a uražené dámy stejnou mincí - operou: ${ }^{9}$ „A byla jedna z nejkrásnějšich paní. Hlas její byl jako violy d'amour. Slanice luhačovská byla v úpalu srpnového slunce. Proč chodila s třemi ohnivými rũžemi a proč vykládala svioj mladý román? A proč byl tak divný jeho konec? Proč zmizel jeji milenec, jak by ho zem pohltila? Nezvěstný vi̊bec. Proč druhému je taktovka spiše dýkou? A dílo lkavé jen tónem, slovem jen ženské, nazváno Osud - Fatum. " ${ }^{10}$ Nicméně než mohl Janáček v roce 1924 takto zavzpomínat na okolnosti vzniku této opery, seběhly se ještě mnohé další události.

Janáček chtěl v roce 1903 v Luhačovicích hlavně zapomenout na všechno zlé, co jej v poslední době postihlo. Jak to známe zvláště ze skladatelovy pozdní tvorby, nejpřirozeněji a nejsnadněji pracuje na novém díle tehdy, když je silně citově angažován. Jeho práce tím získává jasnou vizi a vzniká v relativně krátkém čase. Vrcholné opery inspirované Kamilou Stösslovou vznikaly v první verzi přibližně rok, podobně také Výlet pana Broučka do XV. století, který byl jistě i přičiněním osobního kouzla Gabriely Horvátové zkomponován za pouhých devět měsíců. Naproti tomu Jeji pastorkyňa či Výlet pana Broučka do Měsíce takovou citovou donátorku nemají a Janáček na nich pracuje mnoho let. Osud spadá do první kategorie. Janáček se do mladé a krásné Kamily Urválkové bezhlavě zamiloval a jeho cit byl zř́jmě opětován. Na otázku, jak dlouho vztah trval, neznáme přesnou odpověd'. Podle vzpomínky Zdeňky Janáčkové a vzhledem k dochovaným dopisům patrně někdy do jara roku 1904. Odhalení poměru Janáčka s Urválkovou je spojeno s př́íhodou jako vystřiženou z Merhautovy Andělské sonaty: ,Ale najednou začala nedưvěra, nevím, odkud se vzala. A varovala mne tak dlouho, až jsem začala být na stráżi. Uvědomila jsem si, že je v dopisech mnoho nedopovědeného, že jsou psány pro mne [Janáček nechával Zdeňce číst dopisy, které dostával od Kamily]. A ještě na něco jsem přišla. Leoš, který byl ve všem tak neopatrný a nepořádný, začal najednou pečlivě zamykat psaci stůl a kliče nosil stále u sebe. Byla jsem vždy nedưvěrivější, ale neřekla jsem mu nic. Bála jsem se zkazit naši dobrou shodu a také jsem už měla zkušenosti, že by mi nepověděl pravdu, kdybych naň šla zpř́ma. Jednou ráno - už v zimě - zapomněl přece na klíče a šel se obléci do mého pokojičku. Honem jsem otevřela jeho psaci stůl. Vpredu vidím dopisy, které jsem s ním četla, najednou dále zahlédnu balíček jiných se stejným rukopisem. Bylo tedy správné mé tušení o dvojí korespondenci. Rychle jsem vzala balíček, stưl zamkla a klíce položila zase tam, kde je muž nechal. Kam ted's dopisy. V bytě bylo zima, já neoblečená, v mé ložnici byl on - schovala jsem je do spižírny na chodbě. Chtěla jsem si je přcčist, až odejde do školy. Ale on,

9 O souvislosti námětu opery a jejího inspiračního zdroje v osobě Kamily Urválkové se již dva roky po skladatelově smrti zmiňuje v Lidových novinách Pavel Váša (Lidové noviny, 1930, roč. 38, č. 403, 12. 8. 1930, s. 1); Viz též: STRAKOVÁ, Theodora. Janáčkova opera Osud. Časopis Moravského zemského muzea, 1956, roč. 41, s. 210.

10 VESELÝ, Adolf E. Po stopách Dra. Leoše Janáčka. Brno: Brněnské knižní nakladatelství, 1930, s. 94-95. 
když se vrátil do pracovny a viděl, že nechal kliče ležet, odemkl hned stůl. Přiběhl ke mnè rozčilen:

- Kde jsou me dopisy?

- Já je mám schované.

- Hned mi je vrat'.

- Ale ano, jen co si je prečtu.

- Ne, ne, dej mi je hned, nebo by ja si musel něco udělat.

- Prosil, hrozil, konečně mi slíbil, že si je přečteme spolu. Uvěrila jsem mu a dopisy prinesla. Vytrhl mi je z ruky a schoval.“11

Zdeňka ve svých pamětech dodává, že vztah pokračoval ještě několik měsíců, až dostal manžel Kamily z Brna anonymní dopis a vše si s Janáčkem vyř́íkal. Vzájemná korespondence, ze které se nám dochoval pouhý zlomek, tak náhle ustala. To je verze spíše oficiální, jinou interpretaci umožňuje fakt, že totiž Janáček a Kamila v letech 1905-1909 bývali v Luhačovicích ve stejném čase a dvakrát dokonce $\mathrm{v}$ témže hotelu. ${ }^{12}$ I Zdeňce byla tato skutečnost patrně známa, protože 19. srpna 1907 se manžela $\mathrm{v}$ dopise do Luhačovic táže: „Je tam?"“13 Janáček ji obratem odpovídá: „No, nakonec: - ona je tu - když Ti to tak na srdci leželo!“"14 Naposledy se zřejmě Janáček se svou „velkovévodkyní luhačovickou“ setkal v roce 1909, přičemž je zjevné, jak naznačuje dopis manželce ze 7. září 1909, že jeho city již nadobro ochladly: „Pí. Camilla už je jaksi scvrklá; není ji ani vidět. " 15 To už je však pro vznik opery nepodstatné, proto se vrat'me do Luhačovic roku 1903.

Janáčkův lázeňský pobyt provázel intenzivní společenský život a časté schůzky s Kamilou Urválkovou. Jak jsme již předestřeli, skladatel tentokrát velmi intenzivně zapisoval nápěvky mluvy, které provázely společenský ruch lázeňského střediska. Nedlouho po př́ijezdu do Brna uspořádal své zápisky do fejetonu Moje Luhačovice, který vyšel v časopise Hlídka. ${ }^{16}$ Nalezneme zde osoby, které později budou mít epizodní role v opeře $O s u d$, stejně jako nápěvky, jež se v opeře v přepracované podobě objeví: „Tatuš pá!““ (malé děvčátko), „Když se má Nana a Johan rádi!“" (hlas Kamily napodobující odpověd’ jejího pětiletého synka na otázku „Co je láska?"). Z Luhačovic odjel 8. záŕí na krátkou návštěvu Hukvald, kde navštívil Sládkovu rodinu. Soudě z jeho zápisků, malá Lidka Sládková onemocněla černým kašlem (ve studii Nápěvky dětské mluvy však jako dobu Lidčiny nemoci

11 TRKANOVÁ, op. cit., s. 78-79.

12 PROCHÁZKOVÁ, Jarmila. Janáčkovy Luhačovice - genius loci at genius musicae. Prameny, Luhačovice: 2009, s. 54-55.

13 Dopis je uložen v JA MZM, sign. A 1725. Viz též: PŘIBÁŇOVÁ, Svatava (ed.). Thema con variazioni. Leoš Janáček - korespondence s manželkou Zdeňkou a dcerou Olgou. Praha: Editio Bärenreiter Praha, 2007, č. 179. (Dále pouze Přibáňová)

14 Dopis z 20. 8. 1907 je uložen v JA MZM, sign. D 1207. Viz též: Přibáňová, op. cit., č. 181.

15 Dopis je uložen v JA MZM, sign. A 49 57. Viz též: Přibáňová, op. cit., č. 268.

16 JANÁČEK, Leoš. Moje Luhačovice. Hlidka, 1903, roč. 20, s. 836-844. 
udává prosinec 1902). Záhadou také zůstává, jak se mezi nápěvky z Hukvald dostaly nápěvky Kamily, luhačovických lékařů MUDr. Pavla Blaha a MUDr. Michala Halíka navíc v těsném sousedství nápěvku „S panem bohem přichd’a zas na hrad" a Janáčkovým zápisem data úmrtí rodičů, jenž naznačuje návštěvu rychaltického hřbitova, kde jsou Janáčkovi rodiče pochováni. Je možné, že by Kamila přijela za Janáčkem z Luhačovic na Hukvaldy na návštěvu i se spřátelenými lékaři, kteří vyšetřili dítě skladatelových rodinných prátel, a při té př́ležitosti je Janáček provedl po Hukvaldech? Žádný jiný pramen se k této události nevztahuje. Každopádně se Janáček vrátil 11. zář́i 1903 do Brna s velkým předsevzetím: napsat „moderni““ operu z luhačovického prostředí, která by reagovala na životní prríběh zbožňované prítelkyně.

\section{Hledání syžetu - Fedora Bartošová, Janáčkova věrná spolupracovnice}

Janáček měl pochopitelně na počátku školního roku mnoho organizačních starostí s varhanickou školou a zprvu i s výukou na učitelském ústavu. Jelikož se chtěl věnovat komponování nového díla intenzivně (i s ohledem na špatnou zkušenost s prací na Jeji pastorkyni, na kterou mu téměř nezbýval čas), zažádal si na učitelském ústavu o zdravotní dovolenou, kterou nastoupil 9. listopadu 1903 (natrvalo pak odešel v následujícím školním roce). Od práce na novém díle jej však ještě odvedla revize partitury Její pastorkyně, kterou přijalo k provozování brněnské Národní divadlo. Během těchto povinností promýšlel syžet zamýšlené opery a hledal vhodného libretistu. Nedočkavá Kamila se již 2. ř́ína 1903 v dopise táže, zda Mistr již operu Hvězda Luhačovic napsal a zda jí bude věnována. ${ }^{17}$ Jakmile Janáček odevzdal zrevidovanou partituru Její pastorkyně divadelnímu poslíčku, píše 9. října Kamile: „Vim, že jsem v opeře černě do černého maloval; pochmurná hudba - tak jak můj duch byl [o Jeji pastorkyni]. Ted' bych si přál libreto svěží, moderní, prekypující životem a elegancí - tak ,,román ditěte “ času našeho. Ach kdo mi ho napíse. Tak bych měl plno detailü: povidají, že umím pérem vládnout - ale bojím se mezi literáty. A ti z nich, co se mi nabizejí, znaji jen hrubý hospodský život: a že ducha, který vším životem vane, možno najít zcela blizko, v nás, v naši nám zcela známé společnosti - tak okouzlujiciho, tak pikantniho, tak překvapujicich zpěvü, scén udivujicich - to netuší, proto že ani neznaji toho života, takoví literáti. Ach kdo mi napiše nové libreto?"“18

Vhodného spolupracovníka nakonec nalezl počátkem listopadu v blízkém okolí. Byla to mladičká učitelka Fedora Bartošová, která bydlela ve stejném domě na Klášterním náměstí jako skladatel, a bývala prítelkyní zesnulé dcery Olgy Janáčkové. Na počátek spolupráce Bartošová po třiceti letech vzpomíná: „Bylo to počátkem listopadu 1903 - asi týden po všech svatých, když Leoš Janáček si mne pozval k sobě. Přijela jsem jako učitelka ze Sudoméřic u Strážnice na tři dny 
k matce do Brna, do starého domu pí. Kusové-Fantové na Klášterním náměstí, kde jsme toho času byli bytem a sousedy s Janáčkem a jeho paní Zdenkou. [Olga, dcera, byla tenkráte již mrtvá.] Do bytu Janáčkových nepricházela jsem poprvé, nebot' navštěvovala jsem častěji Olgu, dokud žila. Jako děti jsme si hrávaly, později jsme se bavivaly $i$ vážně, zvláště, když Olga nemocná vrátila se z Ruska, o němž mnoho a ráda vypravovala. Ale - tehdy již ubohá Olga, vždy křehká a průsvitná, byla přislíbena smrti - a všichni to až př́liš dobře tušili. Tedy: do bytu Janáčkových jsme vcházeli všichni vždy s úctou a zatajeným dechem. Za velkou jídelnou byla pracovna Leoše Janáčka, kam mne tehdy v listopadu uvedl. Př́mý účel pozvání jsem předem neznala, věděla jsem jen, že to bude rozhovor literární. Napsala jsem tehdy a uveřejnila několik básní a nějak oklikou jsem se dověděla, že se Janáčkovi jejich forma líbí. Myslila jsem, že se jedná o nějaké písně - ale - Janáček přišel s věci mnohem větši - pro mne grandiosní. Sděloval mi, že má v plánu zpracovat operu, pojmenuje ji bud' Rudé růže, neb Plamenné růže. Přemýšlel již o největšich effektech a hlavních osobách: O Živném, skladateli (hned od počátku žila ve mně predstava, že Živný a Janáček je jedna osoba), o Míle Válkové (to byla ona krásná dáma, jejiž fotografii mél na psacím stole) - o scenerii lázeňské - Luhačovicích, jež v jeho životě hrály velkou roli. Tam prožival své hudebni inspirace, tam léčil své tělesné neduhy, tam sílil a vzpružoval své nervy, prepnuté - jak často bývá u cholerika. O hudebni konservatoři se mi rozhovořil - věděla jsem, že má na mysli Varhanickou školu, která byla jeho radostí a polem, jako oráči, kam své sémě zasévá. Jak hovořil, zapalovaly se jiskérky v jeho očich a já věděla, že jeho fantasie doplñuje scény ze života, jejž prožil - ale, kde ty hranice byly, těžko mi bylo určit - Odcházela jsem z této první domluvy s Janáčkem nadšena, se slibem, že se vynasnažím mu porozumět a vyhovět a dát formu jeho myšlenkám. On sám napiše děj - i jednotlivé scény a já je - zveršuji. A tak za mnou putovaly do Sudoměřic Janáčkovy nácrty scén - dost podrobné, jež jsem celkem neměnila, jen většinou veršsovala. V dopisech, jež doplňovaly zasílané svitky, vysvětloval Janáček osoby, charakterisoval je, odůvodňoval jejich vystoupení a jednání. Ale též jedná se někdy v dopisech o osobách a detailech, jež později z díla vůbec nevypadly. “19

O spolupráci mladičké učitelky a skladatele na nové opeře, spolu se zprávou, že Janáček odchází z učitelského ústavu na odpočinek, ihned informovala Moravská Orlice, ${ }^{20} \mathrm{z}$ čehož skladatel, který ještě v podstatě na díle nezačal pracovat, neměl zrovna velkou radost. ${ }^{21} \mathrm{~V}$ dopise z 12. listopadu Bartošové zaslal textový náčrtek počátku opery, kde zdůraznil základní př́stup ke zpracování textu: „Předně Vás tedy žádám o povšechnou stylisaci. Za druhé o propracování, doplnění, po př́padě i úplnou změnu scen, jak jsem několika slovy po skutečnosti je načrtl. Označil jsem je červenou tužkou 1.\} 2\} 3\} Scena 4\} mohla by vyznět

19 Dopis Fedory Barošové-Lavické Vladimíru Helfertovi ze 4. 12. 1933 je uložen v JA MZM, sign. B 1727.

20 Anonymus v oddíle Hudba. Moravská Orlice, 1903, roč. XLL, č. 275, 29. 11. 1903, s. 14.

21 Dopis je uložen v JA MZM, sign. A 5804. 
spojením těch rưzných po ústřední promenádě hlasů, rekl bych, v hymnus slavnostni na boži krásnou prírodu. Do jejího lesku vstoupila by hlavni osoba, pi Mila Válková. Forma verše mi tane na mysli taková, jak ji Puškin uživá v Oněginu. “22 Jistě se nabízí otázka, proč po prozaickém libretu, jehož významu si byl Janáček dobře vědom, vyžaduje veršované libreto, nadto v čtyřstopém jambu. Odpověd' není složitá. Skladatel totiž navštívil tři dny před sepsáním dopisu v pražském Národním divadle představení Čajkovského opery Evžen Oněgin a patrně byl tímto zážitkem ovlivněn. O podobě, jak byla opera v prvním plánu koncipována, Janáček informoval ve stejné době Kamilu Urválkovou: „Chci míti tedy I. jednání zcela realistické, odkreslené ze života lázeňského. Tam jest motivů bohatost! II. jednání má býti vlastně prelud. Neni tu skutečnosti více, ale do prasknutí nervů podrážděná mysl vede děj dále, tak, že nechává rozpor jest to skutečnost neb halucinace, přelud? Jest-li byla I. jednání scenerie lázně nádherné, tož v II. jednáni má ukazovati přepych interieru dámských pokojü, scenerii jižnich krajin. III. jednáni bude divné. Jest aulou, slavnostni siní, konservatoře. Elévi scházeji se, páni, dámy. Ta známá školská veselost a rozpustilost. Na stěně visí plakát opery - její jméno? Ani nevím ještě. Snad ,Tři růže - neb ,Andělská píseñ ' [patrně inspirace Andělskou sonatou]. Elévi hádají se o opeře. Bylo-li druhé jednání skutečností neb vybájené. Bylo-li vybájené, pak tu byla př́mo choroba duševní. Jest to z uměleckého života. Smetanovi znèl jediný ton sílou elementární v mozku - a byl churav. S mým umělcem bude hůře. On dokončuje v druhém jednání svou operu v daleko větším podráždění. Professor ptá se svých elevi̊: ,Což když by do té rozpěněné krve ponořili Jste výheň skutečného bolu a štěstí lásky? "Snad by byl sešilel' - odpovídá elév. ,Pravi se, že prý sešilel 'podotýká professor. ,Jeho životopis není ani dobře znám - byl prostředním skladatelem. 'Tak by zakončila opera.“"23

V určitých parametrech měl skladatel představu, která se přenesla až do finální podoby díla, avšak celek vznikal mnohým přepracováním, doplňováním a variováním celého př́iběhu. Předtím, než skladatel uznal libreto za vhodné ke zhudebnění, vzniklo několik rozdílných verzí textu, především druhého jednání.

Spolupráce $\mathrm{s}$ Fedorou Bartošovou, která přenášela do veršů Janáčkem zformulovaný prozaický text, začala slibně. Mladá autorka 16. listopadu skladatele požádala dopisem ${ }^{24}$ o ujasnění postavy Živny (tehdy ještě Živna místo Živný patrně dozvuk Andělské sonaty, kde je hlavní postavou Hřivna) - nebylo jí totiž jasné, jestli jde o hlavní postavu př́běhu nebo jen o jednoho z mnoha lázeňských hostů. Navrhuje také omezit všeobecný popis lázeňského života a soustředit se na hlavní dějovou linii. Janáček obratem vše ujasňuje a s návrhy souhlasí. ${ }^{25}$ Patrně paralelně s dopisem skladateli začala Bartošová pracovat na samotném libretu. Týž den se v práci dostala až na konec 4. obrazu, 5. a 6. scénu sepsala o den poz- 
ději, na 7. scéně pracovala 18. listopadu, dále jsme informováni až o dokončení celého 1 . jednání 25 . listopadu 1903 . První verze 1 . jednání byla formálně rozdělena do 16 scén.

Úvod jednání nás zavádí časně zrána do luhačovických lázní s Janovým domem, kolonádou a pramenem Vincentky. Na scéně se objevuje ponocný, služky, pekař a Živný, který pravidelně vychází z hotelu již za svítání. Později se přidávají další postavy: zahradník, nalévačky, správce lázní Hrdlička a první hosté. Přichází i Míla Válková, která se svou krásou stává centrem pozornosti. Správce Hrdlička k ní přistupuje s kyticí aster, dvoří se i Dr. Suda a Konečný. Míla uvidí Živného - skladatele, a chce se s ním seznámit. Tak se také stane. Oba k sobě okamžitě ucítí náklonnost. Přicházejí učitelky, které se přou se skupinou kněžích, zda bude v klavírním salonku zkouška sboru či přednáška doktora Kalamáře. Scéna se plní Žabkami - mladými děvčaty, studenty, je zde i sl. Pacovská, Dr. Suda, továrník Jesenský a Vyjel - později Janáčkem označen jako malíř. Ti všichni se těší na společný výlet, na který se vzápětí vydají. Míla a Živný zůstanou sami. Míla vypráví svůj příběh - milovala skladatele, kterého musela pro odpor rodiny opustit a vzít si bohatého muže, se kterým má syna, ale není s ním št’astná. Zhrzený skladatel se také oženil, a př́iběh nešt’astné lásky vložil do opery. Živný zase vypráví o neštěstí, které změnilo jeho život - úmrtí milované dcery. Vypráví i o potřebě nového vzplanutí pro svou tvorbu. Inspirován Mílou cítí, že nyní může stvořit velkou operu. Přicházejí lázeňští hosté $\mathrm{z}$ výletu. Veselá společnost se s nadcházejícím večerem postupně rozchází. Míla vypravuje Živnému ještě jeden milostný př́běh a daruje mu tři rudé růže. Jako na začátku jednání se objevuje ponocný a zamilovaný pár se loučí.

Bartošová posílala nedočkavému Janáčkovi části jednání a skladatel je zřejmě prripomínkoval a zasílal zpět. Ve spisovatelčině rukopise nalezneme některé změny zapsané Janáčkovou rukou, jako např. začlenění nové postavy Mílina manžela Války či změnu vykání na tykání u dvou hlavních protagonistů. Patrně 25. listopadu se Janáček omlouvá, že Bartošové neposílá náčrtek 2. jednání, jelikož jej nechce posílat po částech, aby měla přehled o dramatickém celku. ${ }^{26} \mathrm{O}$ den později sděluje, že začal s prací na koncepci 2 . jednání. ${ }^{27} \mathrm{~V}$ následujících dnech zaslal Bartošové svou představu 1. obrazu a 29. prosince také 2. obrazu 2. jednání, na kterou Bartošová reaguje 1. prosince ${ }^{28} \mathrm{~s}$ tím, že takto koncipované jednání se jí velmi líbí pro svou dramatičnost i moderní ovzduší. Literátka se tedy pustila do zveršování druhého jednání, které je rozděleno na dva obrazy o pěti a dvou scénách. Děj se ovšem od finální verze naprosto liší.

\footnotetext{
26 Dopis je uložen v JA MZM, sign. A 5800.

27 Dopis je uložen v JA MZM, sign. A 5799.

28 Dopis je uložen v JA MZM, sign. A 177.
} 
První obraz je zasazen do dámského budoáru paní Míly. Míla čte dopis Živného, ve kterém se rmoutí nad jejím stavem. V lázních byla štastná a okouzlující, nyní je však zoufalá. $Z$ dopisu je zřejmé, že Živného k Míle váže silný cit. Vtom přichází služebník Jean, který oznamuje př́íchod Živného. Ve druhé scéně Živný očekává Mílu a v monologu se přiznává, že ztratil jakoukoliv vưli a je slepě veden osudem. Přichází Míla a Živného zaplavuje štěstí, přestože ví, že se s ní musí rozejít a odjet, aby ji neuvrhl do neštěstí. Míla se přesvědčuje o jeho hlubokém citu. Vyčítá mu sice jeho smyslný a citově prázdný vztah k blíže nespecifikované mladé ženě, který však Živný překonal právě díky Míle [více se z textu nedozvíme - zřejmě se jedná o dozvuk Andělské sonáty]. Živný chce Mílu chránit před celým světem i před sebou samým. Míla vytahuje jehlici, pobodá si s ní ruku a Živnému ukazuje krůpěj krve, která je plna vášně. Žádá jej, aby jí pomohl stavět „hráz cti a - povinnosti“. Vtom přibíhá synek paní Míly a táže se, co je to láska. Odpovědět se pokouší i Živný. Vzápětí přichází pan Válek se svými hosty: malířem Lhotským a Dr. Šedým. Živný je všem představen.

První obraz dokončila Bartošová 4. prosince, patrně jej obratem poslal Janáčkovi a hned se pustila do obrazu druhého.

Ten se odehrává na dalmatském pobřeží na terase malé vily, kde je ubytován Živný, jehož přichází navštívit maliř Lhotský. Živný ukazuje Lhotskému dopis z divadla odmítající uvedení jeho opery. Umělci debatují o smyslu svého tvưrčího snažení. Živný touží v díle ukázat duši i pravdu, naproti tomu cynický Lhotský pouze tělesnost a smyslnou krásu, aby se jeho obrazy dobře prodávaly. Lhotský oznamuje Živnému, že na riviéru přijali krajané, mezi nimiž nechybí Míla. Živný se prořekne, že o tom ví z Mílina dopisu. Ten neopatrně zasune do partitury opery. Živný si vyčítá, že v opeře ponížil Mílu i její dítě. V záchvatu zuřivosti a výčitek si splete Lhotského s divadelním poslíčkem a mrští po něm partituru. Lhotský vezme z partitury vypadlý dopis a odchází. Živný se uklidní, až když uvidí přicházející Mílu. Vtom přichází Válek s Lhotským, který ukazuje Mílin usvědčující dopis. V rozčilení Válek vezme dopis, vstrčí jej do hlavně pistole a vystřelí směrem k Živnému, kterého zraní. Zraněna je i Míla. Ta „heroicky“ vysvětluje, že dopis je pouhá lež a vyznává se k lásce ,s níž Bůh bílý je spokojen

a nemůže být rozhněván

i ta ve vášni rozžatá,

jíž věčný zákon v mramor psán

je bez krve $[\ldots]$...

Je zřejmé, že zmatený děj má vážné nedostatky i kvůli neujasněným vzájemným vztahům mezi jednotlivými postavami. Janáčkova představa psychologického zdůvodnění relací mezi postavami je zaznamenána v dopise Bartošové z 29. listopadu: „Psychologicky vysvětluji si druhé jednání tak: pí. Míla V. odmitá, tot' 
přirozené, Živného v I. obrazu. Nepoznala ho. Ví ovšem o jeho lásce a sleduje jisama neštastná. Tím sledováním roste její príchylnost. Když jest svědkyni očisty Živného - musí psychologicky správné i k ní dojíti. K zjevnému výrazu náklonosti. Brutálnost jejího muže dovršuje vše. Umělecký proces se tím zakončuje, že pod fantastickou smyšlenku Živného přijde - pravda za podklad. Neb jen stín prav$d y$ ?"29 Bartošová dokončila 2. jednání patrně před 8. prosincem, protože toho dne jí Janáček zaslal svůj koncept 3. jednání, ${ }^{30}$ které jí nechtěl posílat dř́iv, než bude 2. jednání dokončené. ${ }^{31} \mathrm{O}$ celkovém vyznění posledního aktu píše: „V IIItím jednání jest ještě gradace - spletna smíchaná se smíchem i úžasem - tak snad máme vyhráno! Jest ten lidský život takový!‘32 Poslední akt rozdělený do šesti scén v hlavních rysech odpovídá finální verzi.

Děj se odehrává šest let po 2. jednání v aule konzervatoře. Elévi a elévky se připravují na večerní premiéru nové opery Plamenné rǔže, jejímž autorem je neznámý skladatel. O díle živě diskutují a chtějí se o něm dozvědět víc. Je zde i šestnáctiletý Dubek Urvy - syn Míly. Elév Verva upozorňuje na př́lišnou náklonnost jejich profesora Živného k Dubkovi. Hovoří o postojích k tvorbě i Živného názorech. Nakonec předzpívají části opery. Když se dostanou k části, kde se chlapec ptá matky, co je to láska, Dubek znepokojen odchází dozadu, usedne a přemýšlí. Elévi a elévky pobaveni částí skladby začnou tančit a vznikne vřava, do níž vstupuje Živný. Shovívavě komentuje veselí studentů a táže se, zda jsou již rozdány role. Elevka Součková sděluje, že není obsazena role, kterou neznámý skladatel určil právě Živnému, a táže se, zda se jí ujme. Ten ale odmítá. Studenti prosí Živného, aby jim ukázal originál partitury a o díle jim řekl něco bližšího. Živný vypráví, že znal skladatele opery a povídá jim o něm (resp. o sobě). Prý „vznětlivý duch a prudký byl“, skládal osobité skladby, v nichž byla v rozporu krása a pravda. Obrat se stal vlivem lásky. Začal milovat lidi, rozpory $\mathrm{v}$ jeho díle byly ty tam a dílo bylo plné harmonie a lásky. Avšak jeho opera nemá poslední jednání, které je v rukou božích. Žena, kterou miloval, zahynula, a od té chvíle má v hlavě spoušt' a jeho hudba náhle ztichla. Zatím se venku setmělo a přichází bouře, ve které skladatel cítí doprovod své bolesti. Studenti, polekáni, se schovávají u varhan. Živný propadá v zoufalství ze smrti Míly, v blesku se objeví její obraz. Dubek jej uvidí, vykřikne „Ó, mamá!“ a Živný padá k zemi. Verva poznává, že skladatelem opery je sám Živný.

29 Dopis je uložen v JA MZM, sign. A 5804.

30 Dopis je uložen v JA MZM, sign. A 5803.

31 Dopis je uložen v JA MZM, sign. A 5801.

32 Dopis je uložen v JA MZM, sign. A 5801. 
Závěrečné jednání dokončila Bartošová v Sudoměři 19. prosince $1903^{33}$ a o dva dny později celý text přepsala ${ }^{34}$ Nedočkavému Janáčkovi, který ji upomínal, ${ }^{35}$ jej předala patrně osobně 22. či 23. prosince,,$^{36} \mathrm{kdy}$ se vrátila ze svého učitelského působiště na svátky domů. A jak dokládají Janáčkovy poznámky, byl s její prací nadmíru spokojen:

1.) Plynné, zpěvné verše

2.) zralé $k$ tisku

3.) tak nové, nové!

4.) nejen hlavni osoby jasné, ale i episodni

5.) po velkých monolozich tolik života $v$ pred a za nimi - že se snesou - Ty Luhačovice!

I. jednáni!!

6.) pro velké, i pražské publikum،337

Je zřejmé, že první verze libreta se od finální liší v několika důležitých momentech. Především Míla a Živný se v Luhačovicích teprve seznamují, takže Živný není totožný s Mílinou mladou láskou a nemají spolu dítě. Velký důraz je v libretu kladen na popis lázeňského života od jeho časného rána až do pozdního večera. Zde se Janáček jistě nechal inspirovat svojí milovanou operou Luisa od Gustava Charpentiera, kterou spatřil na scéně pražského Národního divadla 21. května 1903. I zde se setkáváme na počátku 2. jednání s koloritem probouzejícího se města (v kalném ránu na Montmartru vystupuje hadrářka, uhlí̌r, tuláci, prodavači novin, zelinář, mlékařka, metaři a další). Dalším významným rozdílem je pojetí celého druhého jednání, které se od finální verze liší místem děje, dějem samotným a především ústřední myšlenkou. Míla díky postojům svého manžela Války v sobě objevuje vlastní, osobitý způsob lásky k Živnému, na rozdíl od verzí následujících, kdy společné soužití Míly a Živného narušuje Mílina bláznivá matka, která nakonec způsobí rodinnou tragédii. Třetí jednání je pak v hlavních rysech totožné s verzí finální. Do konce roku 1903 vypracovala Bartošová ještě další verzi pod názvem Plamenné růže ${ }^{38}$ která zohledňovala Janáčkovy připomínky: ${ }^{39}$ Zkrátila některé pasáže, především sloučila první čtyři scény 1 . jednání v jednu, takže děj začíná stejně jako ve finální verzi lázeňským ruchem a výstupem básníka, tedy bez líčení brzkého luhačovického rána. Přidala také verše ve 3. jednání, které popisují až démonickou povahu skladatele. Janáček právě do tohoto exem-

Dopis je uložen v JA MZM, sign. A 178.

34 Libreto je uloženo v JA MZM, sign. L 10.

35 Dopis je uložen v JA MZM, sign. A 5802.

36 Dopis je uložen v JA MZM, sign. A 178.

37 Dopis je uložen v JA MZM, sign. A 178.

38 Libreto je uloženo v JA MZM, sign. L 11.

39 Dopis je uložen v JA MZM, sign. A 5803.
} 
pláře později zřetelněji zasahoval, činil mnohé škrty, zaměňoval postavy (do 1. jednání včlenil Lhotského), a prripisoval též notové poznámky.

Je pravděpodobné, že v dalších dnech se Janáček nové opeře nemohl věnovat, protože se blížil 21. leden 1904 a s ním první uvedení opery Její pastorkyn̆a v brněnském Národním divadle. Až po premiéře skladatel opět písemně kontaktoval Bartošovou. Spisovatelka vzpomíná, proč se v dalších měsících podoba libreta neustále měnila: „O Vánocích nastal obrat. Janáček až doposud se svým dílem se tajil. A nyni hledal kritiky, hledal rádce. Byli to prvně asi prátelé z Tebichovy búdy ${ }^{40} v$ Brně, kteři pročitali a kritisovali Janáčkovo libreto (moje verše). A rüzné úsudky přimély Janáčka ke změnám. Počalo prestavováni scen a jednání, (vím, že Janáček jedenkráte i navrhl, aby poslední jednání bylo prvním), změna obsahu scen, seškrtávání, hledáni effektů a též - změna jména opery v - Osud."“41 To se projevilo již v dopise z 27. ledna 1904, kdy zřejmě po kritice textu Janáček znejistěl a Bartošovou požádal, aby nikomu nic z děje opery neprozrazovala. Kromě toho ji poprosil o zveršování vět věnovaných jeho milované „ubohé“ Olze, o které Živný vypráví Míle v 1. jednání: „Život pučel u ní teprve, myšlení začalo se soustřed'ovat v určitý směr - chtěla sloužit myšlence sjednoceni všeho Slovanstva dle slabých svých sil divčich, učitelkou chtěla být ruského jazyka - šla sobě pro posilu a poznání nejmohutnějšiho ze slovanských národů - oni viděli na čele jejím divný stín smrti - smáli se v nemocnici jejímu dychtění! Jak trpěla! To bylo, mimo hrùzy umírání, to nejtragičtější z jejího života." "42

Ve skladatelově pozůstalosti nalezneme kratičkou další verzi 3. jednání psanou rukou libretistky, která patrně pochází právě z ledna roku 1904, do níž si Janáček dělal poznámky. V této verzi Živný $\mathrm{v}$ aule konzervatoře přemítá o své opeře, která má následující večer premiéru. Jelikož Míle slíbil, že se v díle nedotkne nejbolestivějších okamžiků jejich vztahu, naposledy si je přehrává a následně ničí. Nemůže obecenstvu odkrýt nejtragičtější místa Mílina života. Míla zemřela kvůli jeho lásce, proto vychová jejího syna, který se stane následovníkem jeho lidského a uměleckého přesvědčení.

Je pochopitelné, že v mnohém nelogický a nepřesvědčivý syžet celého díla Janáčka neuspokojoval. Na podobu libreta měl zásadní vliv moment, kdy skladatel začal uvažovat o změně, která by celý děj učinila dramatičtější - a sice že Dubek Urvy je dítě Míly a Živného. V dopise z 11. dubna 1904 žádá o vypracování těchto změn s důrazem, že Míla si bere Válku proti své vůli. Navrhuje také, aby první obraz 2. jednání odpadl a celý akt začal až Živného monologem, ve kterém je rozlícen skutečností, že Mílinou svatbou přišel nejen o ni, ale i o svého syna. To je také důvod, proč ji ve své opeře staví na pranýřr. Když se pak s Mílou setká-

40 „Búda otce Tebicha“: pánská společnost brněnských intelektuálů a umělců, mezi něž patř̌il vedle Janáčka např. Antonín Tebich, František Mareš, Josef Merhaut, Dušan Jurkovič, Karel Sokol-Elgart či Jan Kunc. O tom více: DRLÍKOVÁ, Eva. Jak se Janáček stal sousedem akademikem. $S P F F B U$, řada $\mathrm{H}, 2006$, č. 41, s. 53-59.

42 Dopis je uložen v JA MZM, sign. A 5805. 
vá, zuřivě ji žádá o své dítě. ${ }^{43}$ Dva dny poté patrně reaguje na dnes nezvěstnou odpověd' Fedory Bartošové: „I já jsem již proseděl času nad libretem! Pracuji dále na I. jednání, až bude hotovo, pak si spolu na revizi zasedneme. Vrcholem I. jednání bude, že Živný dozvi se, že Urva Dubkưv jest jeho. Neměňte tudiž na I. jednání ničeho. Jedná se hlavně o II. jednání. Živnému vzal Válek nejen ženu ale ted' i ditě: jest-li s vědomím neb ne - na tom tu nezáleži. Živnýv opeře svoji odhalil roušku života pí. Míly - to by bylo ještě ušlo: ted' ale vlastní ditě a jeho matku zpranýroval! Tudiž poodhaluje onu roušku jeho vlastního svědomí - proto pro vše páli partituru! V zuřivosti prozrazuje se tajemství. Hlasy ze společnosti: , Tot' jeho a jeji ditě —! Takový skandál': Osud pí. Míly je de facto zpečetěn - ten není třeba dále vidět ani slyšet: to si každý domyslí. VIII. jednáni se napovídá, že ditě, Urva Dubek, se prece pod vliv otcủ dostal. On snaži se svou duši vlít do Dubka atd. My se tedy obejdeme i bez trpné postavy Válka! Za to vezmeme malého Dubka již do I. jednáni na konec. Též bude Dubek v II. jednáni. Z nynějšiho II. jednáni škrtneme dočasný I. obraz. II. jednáni necháme v těchže láznich v klavírním salonu. Jest v něm Živnýs partiturou - listuje v ní a v monologu odkryje svoji duši: (jak na druhé strané jsem nadhodil). Lhotským zahajuje se 2. scéna; pí. Mílou s Urvou 3. scéna; společnost lázeňská hromadi se a je svědkem odkryté v láznich románové episody.(4. scéna). Tak, prosím na to II. jednáni se pustte." “44

A Bartošová opět vyšla Janáčkovi vstříc. Vypracovala novou verzi 2. jednání dle skladatelových pokynů a ihned mu ji zaslala, jak je patrné z Janáčkovy odpovědi z 28. dubna 1904: „Materiálu pékného Jste mi dodala, že z něho věru ted” možno sestavit pěknou operu. [...] Věru nebyla ani prvni práce špatná; to ted' vím. Ovšem nebyla jen zcela zralá. Uzráni vždy potřebuji času. “"5

Děj 2. jednání je tedy přesunut $\mathrm{z}$ dalmatské riviéry do Luhačovic, kde si Živný u klavíru v salonku listuje v partituře své opery. Uvažuje o Míle a výkvětu jejich lásky dítěti Dubkovi. V opeře chce pravdivě ukázat jejich př́iběh. Dubek má v díle poznat, že se $\mathrm{v}$ umění stejně jako v životě setkává duchovnost s vášní. Přichází Lhotský, kterému Živný povídá o svém díle. Lhotský však upozorn̆uje, že tak nezveřejňuje pouze príběh svojí lásky, ale i velmi osobní a intimní momenty života svých blízkých. Jelikož závidí Živnému jeho invenci, úspěch i Mílu, vnukne mu myšlenku, že dílo nesmí předat veřejnosti. Živný začne přehrávat část své opery a jeho hra přivábí lázeňské hosty. Po chvíli se objeví i Míla s Dubkem. Lhotský opět intrikuje, když Míle sdělí, že dokončená opera nebude nikdy provedena, protože je v ní evidentně vylíčen jejich vztah a proto Živný trpí. Mezitím vchází skupina hostů, kteří nesou Živnému kytici, jako odměnu za silný hudební zážitek. Ten však v záchvatu šílenství a začne

\footnotetext{
43 Dopis je uložen v JA MZM, sign. A 5806.

44 Dopis je uložen v JA MZM, sign. A 5807.

45 Dopis je uložen v JA MZM, sign. A 5811.
} 
pálit partituru. V nastalém zmatku odvádějí Živného. Hosté se s opovržením dívají na Mílu, která i s Dubkem rychle odchází. ${ }^{46}$

S takto koncipovaným 2. jednáním Janáček dále nepracoval, jelikož na rozdíl od zbývajících rukopisů Bartošové v něm nejsou žádné úpravy. Ačkoliv takto z 2. jednání mizí poněkud trapný výstup s Lhotským, ukradeným dopisem a Válkovým vražedným výstřelem, nevysvětluje se zde konec Míly. Jak se dále vyvíjela podoba libreta, není přesně známo. Překvapivé je Janáčkovo sdělení z 22. dubna 1904, kdy píše Bartošové, že dokončil 1. jednání a že „vypilovat“ jej mohou právě jenom v partituře. ${ }^{47}$ To tedy znamená, že skladatel měl 1 . jednání v první verzi dokončené i v partituře. Dochovaná torza autografu partitury skutečně potvrzují, že Janáček zhudebnil ranou verzi libreta 1. jednání. V témže dopise zve Janáček Bartošovou do Luhačovic, kde chtěl společně projít partituru 1. jednání a dohodnout se, jak dořešit jednání druhé. Bartošová měla $v$ Luhačovicích pobývat 11. a 12. května ${ }^{48}$ ale dva dny před smluveným př́jezdem ji Janáček upozornil, že tam po lázeňském životě není ani památky a od cesty ji zrazoval. ${ }^{49}$ Přesto Bartošová přijela: „,...] v Luhačovicich projednávali jsme některý obraz - to je tak poslední z mých vzpomínek na společnou práci s Janáčkem na libretu. Vidèla jsem tehdy poprvé Luhačovice, dějiště (částečné) opery Osud. Bylo tam chladno i deštivo tenkrát, ale mladá zeleň se probouzela, jaro prokukovalo větvemi. Hostů bylo jen několik. Ředitel lázní tehdy doktor Veselý, s úsměvem daroval mně, autorce libreta, $v$ němž ,jeho 'Luhačovice budou žit a zpivat, kytičku konvalinek a udělal společnost nám: Janáčkovi, mé matce a mně, s gestem domácího pána. “50 Poslední dochovaný dopis tvůrčí dvojice je z 2. července, kde skladatel upomíná mladou literátku o libreto. ${ }^{51} \mathrm{Z}$ dalších verzí libreta, které patrně vznikly mezi květnem a červencem 1904, se dochoval trístránkový návrh nového začátku opery zapsaný rukou Bartošové. ${ }^{52}$ Tento začátek Janáček rozpracoval v kompletní rukopisný text opery pod názvem Mami, víš co je láska? (později tento titul zrušil a nahradil jej názvem Fatum (Slepý osud), v němž mnohá místa řeší tak, jak to známe z dnešního znění libreta. ${ }^{53}$ Opera v př́iběhu dostává finální podobu.

První jednání začíná se zataženou oponou, za níž je slyšet zkouška opery. Otevře se opona a jsme uprostřed dění $\mathrm{v}$ aule konzervatoře, kde se studenti připravují na večerní premiéru nové opery svého profesora Živného s ná-

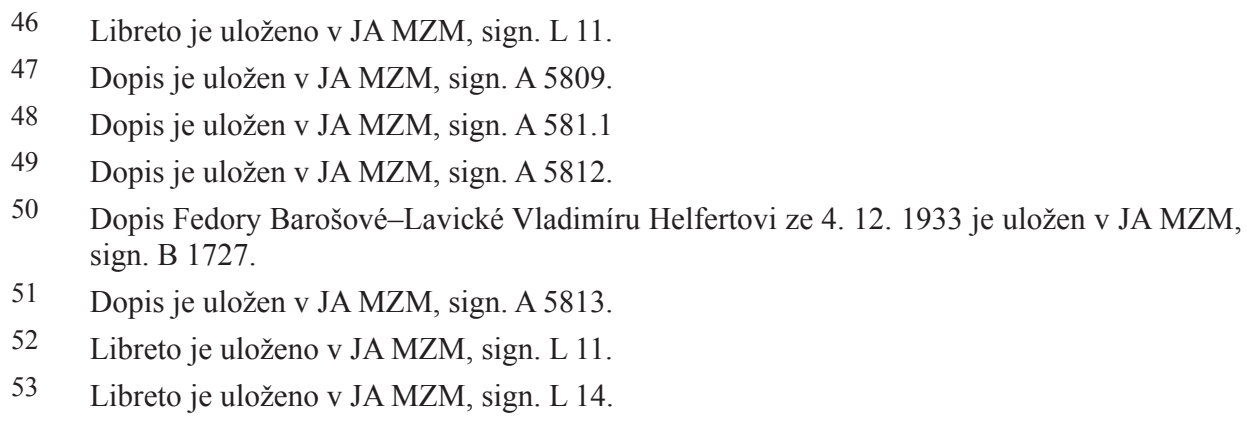


zvem Plamenné růže, které však stále chybí poslední jednání. Mezi studenty je i Doubek. Studenti tuší, že postava skladatele Lenského je ve skutečnosti jejich profesor. Přichází Živný a vypráví o hlavní postavě opery a o díle samotném. Dostává záchvat vzteku a lítosti, a blescích sílící bouřky zahlédne podobu milované Míly. Jeden úder blesku vypíná elektrické osvětlení, které zraní Živného. Ten se probírá a potvrzuje, že opera je bez posledního taktu, který je v rukou božích a zůstane tam. 2. a 3. jednání je vlastně inscenací Živného opery, resp. retrospektivou jeho života. Ocitáme se na kolonádě luhačovických lázní, které jsou plné života a ruchu. Zde se také po delší době potkává Míla a skladatel Lenský, kteří se po velké, vášnivé lásce náhle rozešli. Vysvětlí si nedorozumění, která vedla $\mathrm{k}$ jejich rozchodu, a ve kterých sehrála úlohu intrika Míliny matky. Lenský zjišt’uje, že z jejich lásky vzešlo dítě - Doubek. 3. jednání se odehrává v bytě Lenského, v němž je mladý pár i s dítětem znovu spolu a žijí poklidný život. Lenský pracuje na opeře, která vypráví jeho životní př́běh. Idylu narušuje bláznivá matka Míly, která nakonec přepadne přes zábradlí schodiště a stáhne s sebou i Mílu. Tak přichází Lenský o svou životní lásku a Doubek o matku.

Jak vidno, př́iběh je v podstatě stejný jako ve finální verzi, ale formální uspořádání je jiné. Avšak oproti finální podobě libreta, začíná opera reálným časem pozdějš́ího 3. jednání v aule konzervatoře a príiběh Míly a Živného je vyprávěn jako retrospektiva či formou „divadla na divadle“ - vzpomínkou nebo snad přehráním dvou aktů nedokončené Živného opery. Celé dílo končí ve veristickém duchu dramatickou smrtí Míly a dětským výkřikem „Mami?!“”.

Je očividné, že právě v této verzi učinil Janáček zásadní krok v ujasnění celého syžetu díla. Janáčkův rukopis je plný poznámek a úprav, zčásti zapsaných rukou Fedory Bartošové. Jde však o úpravy ponejvíce jazykové, ne dějové. Patrně zde končí spolupráce Janáčka $\mathrm{s}$ Bartošovou. S takto vypracovaným textem již Janáček pracoval při komponování partitury, ačkoliv i později se její znění ještě několikrát změní.

Spolupráce Janáčka s Bartošovou byla v podstatě harmonická. Mladá literátka ochotně zveršovala Janáčkem dodaný text, v některých momentech rozpracovávala základní děj. Během osmi měsíců vytvořili pozoruhodný text, který svým propojením reálného života tvưrce s jeho dílem nemá v operní literatuře pandán. Poukažme ještě na hlavní postavy, které mají předobraz v reálných osobách, tak jak to doložila Theodora Straková: Míla Válková = Kamila Urválková, Válek = Urválek, Lhotský = maliřr z Hroznové Lhoty Joža Úprka a pochopitelně Lenský $=$ Čelanský. ${ }^{54}$ Jméno Lenský má současně opět souvislost s Čajkovského operou Evžen Oněgin, kterou, jak již bylo uvedeno, Janáček viděl bezprostředně před koncipováním libreta (Oněginem se inspirovala i Kamila Urválková, která se v dopisech Janáčkovi podepisovala jako Tat’ána).

54 STRAKOVÁ, Theodora. Janáčkova opera Osud. Část druhá: Libreto. Látka a tvar. Časopis moravského muzea, 1957, roč. 42, s. $139-140$. 
Zajímavé je, jak Bartošová chápala Janáčkův požadavek, že libreto má býti moderní. Tento výraz totiž velmi často libretistka užívá ve spojení s oděvem, který u dané postavy vždy důkladně popisuje, účesem či v souvislosti se zařízením bytu (moderní obrazy apod.). Tento důraz na vizuální stránku je v operních libretech ojedinělý a díky ženskému pohledu nesmírně zajímavý.

\section{Kompozice - první verze opery}

O samotné kompoziční práci na opeře víme jen málo. Jak jsme již předestřeli, Janáček nejprve komponoval dnešní první jednání na starší verzi libreta od 10. března do zhruba 22. dubna $1904 .{ }^{55} \mathrm{Z}$ této verze se nám dochovalo jen malé torzo. ${ }^{56}$ K práci se zřejmě opět vrátil až v druhé půli roku 1904, kdy komponoval již na nový upravený text s rozvržením - úvod zkoušky za zavřenou oponou - konzervatoř luhačovické lázně - Živného byt. ${ }^{57}$ Autografní znění dokončil zřejmě v polovině roku 1905. Opis partitury, pořízený kopistou Josefem Štrossem, nese pouze jediné datum 14. června 1905 a to na konci dnešního 3. jednání (v době opisu to však bylo 1. jednání). ${ }^{58}$ Opis obsahuje mnohá přepracování. Je zřejmé, že krátce poté, co Janáček oznámil 22. dubna 1904 Bartošové dokončení 1. jednání odehrávajícího se v lázních (pozdějšího 2. a dnes opět 1.) podle libreta z prosince 1903, nechal skladatel tuto verzi Štrossem opsat. Avšak po zpracování další verze libreta, která přináší zásadní změny jako Mílin poměr s Živným ještě před luhačovickým setkáním, jejich společné dítě nebo upravený výstup učitelek a změněný celý závěr jednání, musel Janáček daná místa upravit a přepracovat. Spolu s touto proměnou byl nucen vyřešit mnoho drobnějších úprav včetně změn postav (Jasenský - Lhotský, Hrdlička - Konečný atd). Janáček provedl tyto korekce prrímo do opisu a to ve spolupráci se Štrossem. Jiná byla situace u dalších dvou jednání, protože ty už Janáček komponoval na novou verzi libreta. Štrossův opis tehdejšího 1. jednání umístěného do auly konzervatoře (dnes 3 . jednání) přináší opět doklad, že skladatel pracoval na partituře v několika vrstvách. Jednání v původním Štrossově opise začíná až ve chvíli, kdy Verva okřikuje své spolužáky, aby se utišili, a táže se, kdo půjde na premiéru. To v podstatě odpovídá opět Janáčkovu rukopisném libretu, avšak samostatný Úvod za zavřenou oponou se v Štrossově rukopise nedochoval a je nahrazen verzí pozdější. I v tehdejší verzi 3. jednání (dnes 2. jednání) odehrávající se v bytě - pracovně Živného (Lenského) je zřejmé, že skladatel později opět do opisu výrazněji zasahoval. Změny se týkají především poslední třetiny dějství, kde je patrně původní Štrossův opis nahrazen pozdější verzí.

55 Dopis je uložen v JA MZM, sign. A 5809, list s autografem particella s datací a textem ,můj první autograf", určený patrně Kamile Urválkové, je v soukromé sbírce.

56 Torzo první verze je dochováno na rubních stranách cvičebného partu uloženého v JA MZM, sign. A 7454.

57 Libreto je uloženo v JA MZM, sign. L 14.

58 Opis partitury je uložen v JA MZM, sign. A 23464 
Po dokončení opisu partitury Janáček vypracoval, snad někdy v druhé polovině roku 1905, cvičebný part (tedy jednoduchý klavírní výtah), ${ }^{59}$ který odpovídá tehdejšímu rozvržení jednání i revizi textu. $Z$ drobných změn je patrné, že cvičebný part vznikl až po skladatelových změnách v opisu partitury v roce 1905. Part byl opsán postupně v roce 1906 Hynkem Svozilem (sekundistou a archivářem orchestru brněnského Národního divadla, který zde nastoupil právě v sezoně 1905/06), a reflektoval tak některé následné změny. ${ }^{60}$

\section{Zadání novinky brněnskému Národnímu divadlu - druhá verze opery}

Janáček na opeře pracoval i nadále. To dokládá skutečnost, že 10. července 1905 navštívil černovický ústav pro choromyslné v Brně, aby zde studoval chování a mluvený projev pacientek. Zároveň zde hledal typ pacientky, jejíž onemocnění bylo zapř́ičiněno chorobných strachem o majetek, jako v př́ípadě Míliny matky. Vhodný př́ípad však nenašel. ${ }^{61}$ Dle informace, kterou zaslal Janu Branbergerovi, dokončil revizi opery v červnu 1906: „Tehdy na nábřeži, řekl jsem Vám, že Vám povím titul nové moji opery. Ted’, když jsem již dočista hotov, slibu svému dostavám. Myslím, že nejlepši titul jest Fatum. Zdůraznil bych to, kdyby to šlo, př́davkem slepý osud. Jest to př́hoda románová, $k$ niž jsem složil hudbu." ${ }^{\text {“62 }}$

Po dokončení revize požádal kopistu Hynka Svozila, aby některé přepracované části partitury opsal, a dokončil též opis cvičebného partu s již provedenými změnami. Patrně 7. srpna dostal od Svozila upravenou partituru i klavírní výtah. ${ }^{63}$ Týž den odcestoval na lázeňský pobyt do Luhačovic a partituru i klavírní výtah si mohl odvést s sebou, ale pravděpodobně se vzhledem k operačním zákrokům, které v Luhačovicích podstoupil, opeře př́liš nevěnoval. Jelikož však měl v úmyslu partituru i klavírní výtah po návratu nechat svázat, lze se domnívat, že právě tehdy rozhodl o změně pořadí jednotlivých jednání do dnešní podoby.

První se o provedení operní novinky přihlásilo již 16. června 1906 Brno, re-

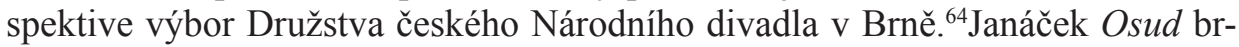
něnskému divadlu přislíbil, jak potvrzuje děkovný dopis z 9. července 1906, kde výbor Družstva Janáčkovi děkuje za slib učiněný 22 . června $1906 .{ }^{65}$ Skladatel zaslal Družstvu své podmínky 9. ř́ijna téhož roku, přičemž žádal novou (myšleno původní) scénickou výpravu, dostačující obsazení orchestru a úhradu výloh. ${ }^{66}$

\footnotetext{
59 Cvičebný part je uložen v JA MZM, sign. A 7454.

60 Opis cvičebného partu je uložen v JA MZM, sign. A 33756.

61 Opis ztraceného zápisníku je uložen v JA MZM, sign. Z 32, dopis tamtéž, sign. A 3319.

62 Dopis z 24. 6. 1906 je uložen v JA MZM, sign. A 5133.

63 Dopis je uložen v JA MZM, sign. A 5449.

64 Dopis je uložen v JA MZM, sign. D 720.

65 Dopis je uložen v JA MZM, sign. D 722.

66 Dopis je uložen v Archivu města Brna, R 35, krab. č. 2, inv. č. 28 - Leoš Janáček. Viz též: FIRKUŠNÝ, Leoš. Dopisy Leoše Janáčka z archivu Družstva Národního divadla v Brně. In
} 
Tyto požadavky byly projednány na schůzi výboru Družstva 18. října 1906: „Přečten dopis p. reditele Janáčka, sdělujici podminky provozování nové zpěvohry ,Osud', $p$. ředitel žádá slušnou výpravu, náhradu výloh s opisem partitury (167 K) a obsazeni orchestru dle partitury. Proti těmto požadavkům neni ovšem námitek; pokud se týče rozšírení orchestru přijdou páni hudebníci po nahlédnutí do partitury s př́slušnými návrhy do plenární schioze. Také návrh, aby se zakoupil k této opeře hudebni materiál, odkládán do plena." ${ }^{\text {67 }} \mathrm{O}$ zadání premiéry Osudu brněnskému divadlu informoval i ř́jnový denní tisk s tím, že opera bude uvedena v březnu 1907. ${ }^{68}$ Janáček vepsal na lístky do partitury nejmenší možné obsazení u dechových a smyčcových nástrojů: 2 flétny, 1 hoboj, 2 klarinety, 2 fagoty, 2 trubky, 3 lesní rohy, 3 pozouny, 4 primy, 3 sekundy, 3 violy, 2 cella, 3 kontrabasy. ${ }^{69}$ Proč tak učinil? Měl totiž velmi špatnou zkušenost s obsazováním brněnského operního orchestru. Nebylo výjimkou, že Jeji pastorkyňa se při reprízách hrála s méně než dvaceti hráči, přičemž některé nástroje nebyly obsazeny vůbec. Jednání o premiéře opery se však zadrhlo a v prosinci roku 1906 žádal Janáček o vrácení partitury Osudu, současně s vrácením Její pastorkyně..$^{70}$ Důvodem mohly být napjaté vztahy s výborem Družstva či špatná úroveň nastudování Jeji pastorkyně v roce 1906. Výbor Družstva však na schůzi 29. ledna 1907 znovu deklaroval eminentní zájem o provedení díla a dokonce navrhl oslovit správce luhačovických lázní, zda by mohl poskytnout nákres lázní tak, aby mohl malî́ pražského Národního divadla Robert Holzer vytvořit scénickou výpravu do Osudu. Mezitím Janáček a poté ředitel divadla Antoš Frýda oslovili malířku Zdeňku Vorlovou-Vlčkovou, která v dopise z 3. ledna 1907 píše o své představě scénického návrhu a kostýmů, přičemž měla k dispozici náčrt luhačovických budov a dokonce chtěla požádat architekta Dušana Jurkoviče o podobu dosud nerealizovaných staveb. ${ }^{71}$

V prosinci 1906 jsou také datovány opisy zpěvních partů, rozepsané opět Hynkem Svozilem, které byly pořízeny pro brněnské divadlo. Režii inscenace začal již v březnu 1907 připravovat Karel Komarov, který promýšlel celkovou koncepci a výtvarné řešení pro úzké jevišstě divadla na Veveří ulici. ${ }^{72}$ Dle vzpomínky pěvkyně Leopoldiny Svobodové, která měla ztvárnit roli Míly, začaly dokonce i korepetice sólistů. ${ }^{73}$ Nicméně obrat nastal ve chvíli, kdy redaktor Artuš Rektorys v dopise patrně z 14. května 1907 Janáčkovi doporučil, aby se s premiérou Osu-

Musikologie I. Praha - Brno: Melantrich - Pazdírek, 1938, s. 131.

Zápisy ze schůzí jsou uloženy v Archivu města Brna, R 35, inv. č. 4.

Olomoucká Snaha 20. 10. 1906. Viz též: STRAKOVÁ, Theodora. Janáčkova opera Osud. Časopis Moravského zemského muzea, 1956, roč. 41, s. 212.

Opis partitury Osudu je uložen v JA MZM, sign. A 23464.

Dopis Antoše J. Frýdy Leoši Janáčkovi z 11. 12. 1906 je uložen v JA MZM, sign. D 719.

Dopis Antoše J. Frýdy Leoši Janáčkovi JA MZM, sign. A 275.

Dopis Karla Komarova Leoši Janáčkovi z 26. 3. 1907 je uložen v JA MZM, sign. A 3472.

Dopis Leopoldina Svobodové Aloisi Staňku Doubravskému z 16. 4. 1913je uložen v JA MZM, sign. A 3931. 
$d u$ obrátil na nové Městské divadlo na Královských Vinohradech, které se mělo koncem roku 1907 otevř́t v Praze. ${ }^{74}$

\section{Nové naděje - nová verze opery}

Činorodý Rektorys již 17. května 1907 informoval Janáčka, že po rozhovoru s dirigentem Ludvíkem V. Čelanským, dirigentem a šéfem opery vinohradského divadla (který jistě netušil, že se ho libreto opery osobně týká), doporučuje Osud ihned zadat Městskému divadlu. ${ }^{75}$ Čelanský by se prý sám ujal nastudování a ubezpečuje Janáčka, že nově ustanovený padesátičlenný orchestr je vynikajících kvalit. Janáček tedy poslal 29. května partituru opery řediteli vinohradského divadla Františku Adolfu Šubertovi ${ }^{76}$ který obratem vyrozuměl Janáčka, že ihned předá partituru dirigentovi Čelanskému na posouzení. ${ }^{77}$ Janáček ale nelenil a již 5. června se vydal do Prahy, aby si o díle s Čelanským ${ }^{78}$ promluvil osobně. Skladatel jej navštívil v bytě ve Spálené ulici a přehrál mu operu na klavír. Čelanský i jeho chot', stejně jako př́tomný Rektorys, byli hudbou hluboce zasaženi. ${ }^{79}$ Krátce nato, 7. června, si vyžádal opis libreta ředitel Šubert, aby jej jako zkušený dramatik mohl posoudit. ${ }^{80}$ Připomeňme, že v roce 1891 ještě jako ředitel pražského Národního divadla Šubert uvedl Janáčkovo pásmo Rákoš Rákoszy a později odmítl provedení opery Počátek románu. Požadavek libretní knížky se ukázal jako problém. Janáček měl pouze své pracovní libreto se spoustou škrtů, ${ }^{81}$ které navíc již neodpovídalo stavu v přepracované partituře. Proto požádal Šuberta, aby nechal z partitury libreto vypsat. ${ }^{82}$ Týž den poprosil o pořízení textové knížky také Rektoryse. Z dopisu je zřejmé, jak se Janáček Šubertova úsudku obával: „Bojím se kritického ducha, spisovatele Šuberta! Vím, že naprosto jasná charakteristika osob a děje vyplývat má v Osuduz výtečné hry zpivajicich - a z analogie životnich poměrü. Tolik podnètů je v těchto třech románových obrazich - aby posluchač mohl ze svého doplňovat co na jevišti jen nadhozeno bud' situací, snad i slovem i pohybem. Tak např. Živnýs pí Mílou (I. obraz) nemohou na prostranství lázeňském - pozorováni a sledováni - tak mluvit (podrobně do úplna), jak

74 Dopis je uložen v JA MZM, sign. B 316. Viz též: REKTORYS, Artuš (ed.). Korespondence Leoše Janáčka s Artušem Rektorysem. Praha: Hudební matice Umělecké besedy, 1949, s. 39, Janáčkův archiv 4 (dále JA 4).

75 Dopis je uložen v JA MZM, sign. B 317. Viz též: JA 4, op. cit., s. 40.

76 Kopie dopisu je uložena JA MZM, sign. A 5160 (orig. Národní památník písemnictví). Viz též JA 4, s. 41-42.

77 Dopis z 30. 5. 1907 je uložen v JA MZM, sign. A 3451.

78 Dopis Leoše Janáčka Artuši Rektorysovi z 5. 6. 1907 je publikován v JA 4, op. cit., s. 43.

79 JA 4, s. 41.

80 Dopis je uložen v JA MZM, sign. D 262.

81 Libreto je uloženo v JA MZM, sign. L 14.

82 Dopis z 8. 6. 1907 je uložen v Nadaci Leoše Janáčka (dále NDJ), sine sign. 
by situace knižně se musela do všech záhybů vyslovit. Nadhodí tolik - kolik jim třeba na dorozumění. Právě volil jsem tu zrovna misty pavučinovou orchestraci, aby každé slovo bylo srozumitelno a náladově doplněno. Do textu patř̀ i těch nèkolik slov úvodových napsaných na titulních listech každého obrazu. Nebude toto stanovisko literáta tak vážného zrna jakým je ředitel Šubert malicherné? Škoda, že jsem nemohl o tom s řed. Šubertem tak mluvit, jako o hudebni stránce s p. Čelanským." "83

Nejistota v otázce kvality libreta byla posílena dopisem Karla Komarova z 3 . června 1907, ve kterém se vzdává režie př́ípadného brněnského nastudování kvůli novým poměrům $\mathrm{v}$ brněnském divadle, ale i pro komplikovanost díla, které je jen velmi těžko inscenovatelné. ${ }^{84}$ Věrný př́tel Rektorys se ihned pustil do práce. Nejprve navštívil Čelanského, od kterého zjistil, že opis libreta je již zadán archiváŕi divadla Josefu Nademlejnskému. ${ }^{85}$ Domluvil také, aby text opery před Šubertem přehlédl Dr. František Skácelík, literární a činoherní referent Radikálních listů. ${ }^{86}$ Janáček obratem požádal o tuto službu samotného Skácelíka, který vstřícně souhlasil. ${ }^{87}$

Prázdninové týdny pomalu ubíhaly. Nedočkavý Janáček, který měl na dosah ruky splnění svého snu dobýt Prahu, i když ne Její pastorkyní v Národním divadle, začal být neklidný. Jeho nervozita stoupla, když byl 23. srpna 1907 vyšel v Národních listech článek, kde byly zveřejněny tituly některých her přijatých do nové sezóny vinohradského divadla, ale Osud mezi nimi chyběl ${ }^{88}$ Janáček ihned požádal Rektoryse o zjištění situace přímo v divadle. ${ }^{89}$ Poháněn nejistotou ani nepočkal na odpověd' a hned další den vznesl dotaz na uvedení Osudu k řediteli Šubertovi. ${ }^{90}$ Ten ho obratem ujistil, že Osud byl Městským divadlem, jak mu již před časem sdělil, přijat (takové oznámení se však nedochovalo a patrně v písemné formě ani neexistovalo). Zároveň skladateli vysvětlil, že oznámení o přijatých novinkách divadlo zveřejňuje postupně a poprosil ještě o zpřesnění názvu díla, jelikož uvádí názvy dva - Fatum a Osud. Opětovně jej také žádá o zaslání libreta. ${ }^{91}$ Př́ítí den, 27. srpna 1907, skutečně vyšla v Národních listech zpráva: „Městské divadlo Kr. Vinohradů. Českou operní novinkou bude nové dílo skladatele Leoše Janáčka ,Osud', komponované na slova Fed. Bartošové. Tou

\footnotetext{
83 Dopis je uložen v JA MZM, sign. A 5161. Viz též: JA 4, s. 44.

84 Dopis je uložen v JA MZM, sign. A 3425.

85 Opis libreta je uložen v JA MZM, sign. L 15.

86 Dopisy jsou uloženy v JA MZM, sign. D 242, 241. Viz též: JA 4, s. 45, 47.

87 Dopis z 18. 6. 1907 je uložen v JA MZM, sign., A 3440.

88 Anonymus. Divadlo. Městské divadlo Královských Vinohradů. Národní listy, roč. 47, č. 232, s. 4.

89 Dopis je uložen v JA MZM, sign. A 5164. Viz též: JA 4, s. 48-49.

90 Dopis je uložen v NLJ, sine sign.

91 Opis dopisu je uložen v NLJ, sine sign.
} 
prací bude také proslulý komponista poprvé uveden na jeviště velké Prahy jako skladatel operni. “92

Janáček tak stál před nelehkým úkolem; vyřešit podobu libreta tak, aby obstála před ředitelem Šubertem. Naději vkládanou do Skácelíkovy revize textu pomalu ztrácel, protože za tři měsíce od něj neměl žádnou reakci. Proto také pobízel Rektoryse, aby Skácelíka upomínal. ${ }^{93}$ Skácelík jej ubezpečil, že na revizi pracuje, a Janáčka požádal o zodpovězení několika otázek, na které dosud nedostal odpověd'. Je možné, že právě v té době vznikly poznámky k jednotlivým dějstvím, kde si Janáček ujasňoval dějovou linii i psychologické vztahy jednotlivých postav. ${ }^{94}$ Obsáhlou odpověd' obdržel Janáček od Skácelíka 27. záŕí 1907, ve které skladatele seznamuje s možnými úpravami libreta. Skácelík sděluje, jak se pokoušel přepracovat scény do reálnější divadelní podoby podle již dané dějové osnovy, ale nebyl s úpravami spokojen. Uvažoval proto, že na základě dané látky, která je k dramatickému zpracování jako stvořená, vytvoří nové libreto. Protože taková práce by však zabrala nejméně půl roku a divadlo potřebuje urychleně operu provést, od takového řešení upustil. Největši problém spatřuje v nepoměru mezi popisem prostředí a jednáním hlavních postav, stejně jako v nejasném zakončení jednotlivých jednání, které vedou k nelogickému propojení děje. Nesouhlasí ani s dikcí, které vyčítá prŕilišný lyrismus, malou dramatičnost a přehnanou dekorativnost. Doporučuje, aby libreto přehlédl ještě básník a dramatik František Xaver Svoboda. ${ }^{95}$ Janáček ale nemohl s revizí textu otálet a tak si smluvil se Skácelíkem na 8. října schůzku, po které spolupráce, i když bez významnějších výsledků, pokračovala. ${ }^{96} \mathrm{O}$ den později si Janáček nechal zaslat z Městského divadla partitury, aby do nich mohl zaznamenat nové úpravy. Týž den také poslal Skácelíkovi dopis $\mathrm{s}$ návrhem změny $\mathrm{v}$ závěru 1 . jednání. Závěr zkrátil a přidal sdělení, ze kterého se Mílina matka hledající dceru dozvídá, že Míla odcestovala se Živným. ${ }^{97} \mathrm{Na}$ tento návrh však nedostal žádnou odpověd’ ${ }^{98}$ Přes literátovu netečnost mu Janáček již 28. ř́íjna zasílá další verzi závěru 1 . jednání, ${ }^{99}$ která pouze nepatrně dotvář́ verzi zaslanou 10. ř́ijna. Je to verze, která až na drobnosti přešla i do partitury - včetně závěrečného komentáře Konečného, Lhotského a Sudy „Luhačovský román!" Prosí též Skácelíka o radu, jak otevřít scénu a rozpracovat začátek 3. jednání. První část práce Janáček od Skácelíka dostal patrně až 4. listopadu. Text je v podstatě rozpracovaný Janáčkův návrh závěru 1. jednání, s důrazem na vývoj

Anonymus. Divadlo. Městské divadlo Král. Vinohradů. Národni listy, roč. 47, č. 236, s. 3.

Dopis z 11. 9. 1907 je uveden v JA 4, s. 53-54.

Komentář k libretu je uložen v JA MZM, sign. L-I-4.

Dopis je uložen v JA MZM, sign. B 816.

96 Dopis Františka Skácelíka Leoši Janáčkovi z 2. 10. je uložen v JA MZM, sign. A 1727.

97 BARTOŠ, František. Janáčkovy dopisy dr. Fr. Skácelíkovi. Tempo, 1947-48, roč. 20, s. 245 246.

98 Ibid., s. 246 ,

99 Ibid., s. 246-247.
} 
duševního stavu Míliny matky. ${ }^{100} \mathrm{~V}$ té době však již měl Janáček závěr prvního jednání vyřešený a zanesený do partitury a proto ze Skácelíkovy práce nic nepoužil. Krátce nato, 14. listopadu, poslal Skácelíkovi verzi závěru 2. dějství a začátku 3. dějství. ${ }^{101}$ Závěr 2 . jednání řeší rozpracováním motivu bouřky, kterou končí ve 3. jednání celá opera, a zároveň přináší na scénu tělo Míly, aby bylo zřejmé, že tragicky zahynula. To také Janáček zahrnul i do partitury. Podstatnější je úprava úvodu 3. jednání. Především začlenil samostatný úvod za zavřenou oponou přímo do jednání. Zrušil zavřenou oponu a celý děj uvedl ranní zkouškou na konzervatoři, na kterou přicházejí studenti. Provedl také v celém jednání drobné korekce. Na tyto návrhy textových úprav již Skácelík nereagoval. Veškeré změny Janáček zaznamenal do partitury, opis rozsáhlejších úprav nebo nově zkomponovaných částí provedl opět Hynek Svozil, z malé části také Vojtěch Ševčík (do roku 1905 hornista brněnského divadelního orchestru, později působící v Praze právě v Městském divadle na Královských Vinohradech). Tuto revizi provázela také změna jména hlavní hrdinky z Míly Válkové na pouhou Mínu, kterou provedl Svozil v celé partituře i klavírním výtahu. Jméno Mína používá Janáček také v dopisech Skácelíkovi. Proč tak učinil, nevíme. Mohlo jít o záměrné odtržení jména postavy od reálné ženy (Míla Válková - Kamila Urválková), snad s ohledem na Čelanského. Nabízí se také možnost, že se Janáček blíže seznámil s dramatem Jaroslava Hilberta Vina, který byl v té době velmi populární a v některých momentech blízký námětu $O s u d u .{ }^{102}$ I zde se objevuje u Míny motiv jakési viny z mládí, komplikovaný vztah s matkou i nemohoucnost se oprostit od dřívějších selhání, která zde vyúst'uje její sebevraždou skokem z okna:

Mladá dívka Mína má přítele Stán̆u, kterého velmi miluje. Mínina matka, která má s dcerou komplikovaný vztah, její volbu neschvaluje, protože Stáňa je nemajetný. Zato Mínin bratr Jiř́ je vztahem sestry s jeho kamarádem nadšený. Mezi Mínou a Stáňou je však cosi nevyřčeného - jakási vina, kterou v sobě Mína nese, a kterou se neodvažuje snoubenci svěrit. Jiří je sochař a přijde $\mathrm{k}$ němu zájemce o jeho dílo - cukmistr Uhliřr. Mína je zneklidněna a v soukromém rozhovoru s Uhlírem vyjde najevo príčina jejího pocitu viny. Před léty totiž jako mladinké děvče udržovala s Uhlířem poměr. Uhliř ji nyní žádá o ruku a nutí Mínu, aby řekla pravdu Stáňovi. Mínina matka je s Uhlírem spokojena, avšak do soukromí Míny se nemíchá. Mína vše řekne Stáňovi, který jí opovrhne a nešt’asten odejde. Psychicky zlomená Mína souhlasí se sňatkem s Uhlířem, jako odčinění své viny. Příčinu všeho však vidí především v matce, o které je přesvědčena, že ji nikdy nemilovala, nekomunikovala s ní a kvůli tomu mohlo před lety u Míny dojít k morálnímu selhání. Jediný Jiří jí porozumí. Stáňa se vrací k Míně, prosí ji za odpuštění za svou reakci a přemlouvá

100 Dopis a libreto je uloženo v JA MZM, sign. A 4750, L 12.

101 Dopis je uložen v JA MZM, sign. A 5195, viz BARTOŠ, op. cit., s.247-48.

102 Na problém poprvé upozornila STRAKOVÁ, Theodora. Janáčkova opera Osud. Část druhá: Libreto. Látka a tvar. Časopis moravského muzea, 1957, roč. 42, s. 149-150. 
ji, aby vzala zpět své slovo dané Uhliřrovi. To však již není možné a Mína řeší situaci sebevraždou skokem z okna.

Není př́liš jasné, kde by se Janáček s dramatem Vina mohl setkat. V roce 1907 pražské ani brněnské divadlo Vinu neuvedlo a ani v skladatelově knihovně text dramatu není, ačkoliv druhé vydání vyšlo právě v roce 1906. Pravdou zůstává, že krátce po změně Míly na Mínu v partituře i klavírním výtahu došlo k dalšímu prepisu a to zpět k původní podobě jména. Míla je také uváděna v opisu libreta, který po revizi poř́́dil opět Hynek Svozil. ${ }^{103}$ Libreto si opsal v průběhu revize i sám Janáček a připojil k němu rozsáhlou stat' věnovanou své opeře. ${ }^{104}$

Po intenzivní práci zaslal 18. listopadu 1907 opravenou partituru, klavírní výtah i nově vypracovanou libretní knížku do Prahy k rukám ředitele Městského divadla Šubertovi. ${ }^{105}$ Zajímavé je, že ještě na konci prosince 1907 projevil opět zájem o studium choromyslných, aby co nejlépe pochopil duševní stav Míliny matky: „Osměluji se Vás žádat, abyste mi umožnil poslechnouti si choromyslné ženského oddělení ústavu pražského. Účel mám dvojí; jednak jde mi o melodii mluvy choromyslných vi̊bec, jednak hledám zvláštni př́pad, kde byla př́činou onemocnèni lakota. Bohatá vdova nechtěla vydat dceru svoji za ,žebráka ' umèlce. Když k sňatku prece došlo, zešilela. Bála se, aby nebyla okradena i o skřrinku se skvosty. Jednou při úleku seskočila se schodiště a zabila se. Tot'v krátkosti typ, který jest řídký snad; nenalezl jsem jej ani v brněnském ústavu choromyslných. “106 O návštěvě pražského ústavu informuje svou chot’ 30. prosince $1907 .{ }^{107}$

\section{Vinohradský př́pad}

Všechno naznačovalo, že po odmítnutí Její pastorkyně v pražském Národním divadle uvede premiéru Janáčkovy novinky nově otevřená pražská scéna a skladatel dostane př́ležitost v Praze prorazit. Hned 1. prosince 1907 byl vedením divadla ubezpečen, že $O s u d$ se rozepisuje a jakmile bude rozpis dokončen, začne se s nastudováním. ${ }^{108}$ Janáček si musel oddechnout, protože mezitím stáhnul uvedení opery v brněnském Národním divadle. O uvedení Osudu ještě nějakou dobu bojoval Janáčkův obdivovatel, člen výboru Družstva českého Národního divadla v Brně, MUDr. Jaroslav Elgart, který skladatele znovu požádal 29. června 1908 o svolení k provedení opery, kdy také vysvětlil, proč o dílo tolik stojí: „Tím tiže nesu zprávu Vaši, že nesouhlasite ku provozováni ,Osudu'. Rád věřm, že Vám - umělci bohem posvěcenému - málo na Brnu záleži. Vaše budoucnost teprve

103 Opis libreta je uložen v JA MM, sign. L 131.

104 Libreto a komentářem je uloženo v JA MZM, sign. L-IV- 2.

105 Dopis je uložen v NLJ, sine sign.

106 Dopis neznámému lékaři je uložen v JA MZM, sign. A 3319.

107 Dopis je uložen v JA MZM, sign. A 3835. Viz též: Přibáňová, op. cit., č. 187.

108 Dopis je uložen v JA MZM, sign. D 773 
přijde a na uznání dneška a Brna netřeba velkým lidem apellovat. - Ale kterak přijdeme $k$ tomu my, kteři z nedostatku velké scény svioj hudebni hlad chceme alespoň illusemi tišiti při skrovných poměrech? Dobře, at'si Vám na tom nezáleži, aby Osud byl v Brně dáván - ale my po něm toužíme!"109 Janáčkova odpověd' z 8. července 1908 je velmi př́krá, ale musíme uváźit značně nepřátelský postoj některých členů výboru brněnského divadelního družstva, kteří všemožně bránili novému nastudování přepracované verze Její pastorkyně, stejně jako vstupu Janáčka do řad Družstva: „Prosím, neračte se dožadovat partitury ani klavírního výtahu, Osudu 'na Vinohradském divadle. Požádám i o ,Pastorkyni 'zpèt. K tomu mne přimělo, když dovidám se podrobnosti o moji volbě. Kde neni uméleckého presvědčení, nemũže se o umělecké práci mluviti a divadlo má jí býti v prvé radě posvěceno. Promiňte, ale jestli se co mého v brněnském divadle ted' dává, na tom zcela nic nezáleží. " ${ }^{110}$ Další reakce je již daleko vstřícnější a ukazuje spíše na skutečnost, že skladatel nechtěl dílo pustit do dalších divadel, než jej alespoň jednou uslyší. To také píše 31. července 1908 Elgartovi: „A ted's Osudem. Velectěný přiteli, kdybych již slyšel aspoň zkoušku některé partie z Osudu na př. bouři v II. jednáni [!] neb cokolvěk jiného a tak byl přesvědčen o účinku aspoň některých částí - myšlená skladba a živý zvuk jsou někdy daleko od sebe - tož bych řekl ano neb ne. Proto prosím Vás, poshovte s Osudem. "111

V Městském divadle na Královských Vinohradech, které přislíbilo Osud uvést ve své první sezóně 1907/08, se zatím ve věci nastudování nic nového nedělo. Janáček po dalším rozhovoru s Čelanským začal pochybovat, jestli k uvedení Osudu hned v první sezoně nového divadla vůbec dojde. ${ }^{12}$ Rektorys v dopise z 8. dubna 1908 vysvětluje př́činy, proč se opera dosud nezačala v Městském divadle zkoušet. Údajně totiž nebyl nový ansámbl ještě natolik sehrán, aby si mohl troufnout na tak náročné dílo. Ubezpečuje však Janáčka, že počátkem podzimu bude Osud určitě nastudován. ${ }^{113}$ Informuje jej také, že orchestrální materiál je již rozepsaný. ${ }^{114}$ Hlasy rozepsal opět Vojtěch Ševčík, který působil v orchestru vinohradského divadla. Když však ani na podzim divadlo neprojevovalo o operu žádný zájem, poradil v dopise z 28. ř́jna Rektorys Janáčkovi, aby na ředitelství divadla přislíbené nastudování vymáhal. Reakci divadla pak slíbil uveřejnit v časopise Dalibor (nic však neuveřejnil). ${ }^{115}$ Janáček tak učinil dopisem z 1. listopadu $^{116}$ a vzápětí mu Jan Heberle jménem ředitelství Městského divadla sdělil, že Osud se v hracím plánu zatím nevyskytuje a může být nastudován až po lednu

109 Dopis je uložen v JA MZM, sign. B 801.

110 Dopis je uložen v Archivu města Brna, R 35, krab. 9, inv. č. 64.

111 Dopis je uložen v Archivu města Brna, R 35, krab. č. 2, inv. č. 28 - Leoš Janáček. Viz též: FIRKUŠNÝ, op. cit., s. 132-133.

112 Dopis je uložen v JA MZM, sign. B1482. Viz též: JA 4, s. 84.

113 Dopis je uložen v JA MZM, sign. B 307. Viz též: JA 4, s. 85-86.

114 Rukopisné orchestrální hlasy jsou uloženy v Archivu Národního divadla Brno, sign. 1-28.

115 Dopis je uložen v JA MZM, sign. B 304.

116 Dopis je uložen v NLJ, sine sign. 
1909. ${ }^{117}$ Leč ani po lednu se situace nezměnila a o Osudu se na dlouhou dobu přstalo úplně mluvit.

A není divu. Provoz vinohradského divadla totiž od počátku provázely značné potíže. Počínaje otevřením této pražské scény 18. listopadu 1907 se divadlo potýkalo s finančními problémy. Bylo to dáno velkým počtem zaměstnanců i nevytíženými soubory činohry, opery i baletu působícími v jedné budově, stejně jako nesnází každého začínajícího divadla - nutností budování fundusu, archivu atp. Ředitel divadla František A. Šubert, stejně jako šéf opery Ludvík V. Čelanský a dramaturg Jaroslav Kamper zprvu sice usilovali o dramaturgickou exkluzivitu, ale divadlo upadalo do stále větších dluhů. Čelanského tvrzení, že Osud chtěl skutečně uvést hned po sehrání souboru, ${ }^{118}$ je jistě pravdivé. Situace v divadle se však náhle vyhrotila. Po výhradách výboru družstva divadla směrem $\mathrm{k}$ vedení ředitel Šubert nečekaně rezignoval. S ředitelem v podstatě odešel i šéf opery Čelanský (měl naplánovanou práci v Paříži), propuštěn byl i dramaturg Kamper. V divadle vypukla 24. záríí 1908 stávka. Situace se postupně uklidnila a po provizorním vedení Janem Hebrlem stanul v čele Městského divadla 29. února 1909 Václav Štech. Ale i když byla dramaturgie upravena s důrazem na návštěvnost, finanční situace se stále nelepšila. Proto byl v polovině roku 1914 odvolán i Štech. Takové ovzduší a dramaturgické směřování divadla uvedení Janáčkova Osudu jistě neposloužilo.

Janáček se o uvedení Osudu v Městském divadle začal opět zajímat v lednu 1911, v souvislosti s pozváním Václava Štecha na nové nastudování Její pastorkyně v brněnském Národním divadle. ${ }^{119}$ Ten se sice z návštěvy představení omluvil, ale slíbil, že stran $O s u d u$ vše zjistí. ${ }^{120}$ Janáček se pokoušel využít situace a nabídl vinohradskému divadlu také Její pastorkyni. ${ }^{121}$ Místo jednání o Jeji pastorkyni se však Janáček dočkal strohého vyrozumění, že $O s u d$ nebyl doposud proveden, jelikož se v archivu nenalézá ani smlouva ani usnesení výboru o tom, že divadlo operu přijalo k nastudování. ${ }^{122}$ Janáček upozornil na existenci Šubertova dopisu z. 26. srpna 1907 i ústní ujištění některých členů výboru družstva. ${ }^{123}$ Štech zřejmě pochopil možné těžkosti stran Osudu a tak si 22. dubna 1911 vyžádal od Janáčka klavírní výtah Její pastorkyně, ${ }^{124}$ který jej obratem zaslal. ${ }^{125}$ A opět se opakovala situace, kterou Janáček zažil před osmi lety s pražským Národním divadlem. V dopise z 26. června 1911 Štech vrací klavírní výtah Její

117 Dopis ze 4. 11. 1908 je uložen v NLJ, sine sign. Viz též JA 4, op. cit., s. 100.

118 Interviev. Národní obzor 27. 6. 1913. Viz též: JA 4, op. cit., s. 109.

119 Dopis z 28. 1. 1911 je uložen v NLJ, sine sign.

120 Opis dopisu z 31. 1. 1911 je uložen v NLJ, sine sign.

121 Opis dopisu z 10. 2. 1911 je uložen v NLJ, sine sign.

122 Opis dopisu ze 17. 2. 1911 je uložen v NLJ, sine sign.

123 Dopis z 24. 2. 1911 je uložen v NLJ, sine sign.

124 Dopis je uložen v JA MZM, sign. D 710.

125 Dopis z 24. 4. 1911 je uložen v NLJ, sine sign. 
pastorkyně s konstatováním, že „pastorkyni není možno uvésti na naše jeviště.“"126 To Janáčka rozčílilo a vedlo k rozhodnutí prosadit uvedení Osudu v Městském divadle i za cenu soudního sporu. Skladatel si s ředitelstvím divadla vyměnil několik dopisů, v kterých obě strany pořád dokola opakují svá stanoviska. A tak Janáček předal řešení sporu právníkovi, JUDr. Adolfu Stránskému. Ten 13. září 1911, zatím v přátelském duchu, adresoval ředitelství vinohradského divadla výzvu, aby bud'to dílo provedlo či zaplatilo jeho mandantovi ušlou škodu. ${ }^{127}$ Následovaly výměny názorů na právní relevanci dopisu ředitele Šuberta a ústní dohody namísto písemné smlouvy a vzájemné návrhy řešení celé kauzy. Výsledkem vyjednávání byla smlouva, v níž se Městské divadlo na Královských Vinohradech zavázelo provést Osud v zimní sezóně 1912/13 a vyplácet skladateli 6\% tantiém ze vstupného. Janáček tuto smlouvu podepsal 8. prosince 1911, ${ }^{128} 20$. prosince byla zaslána smlouva parafovaná Štechem. ${ }^{129}$ Zdálo by se, že tím je dlouhá historie uvedení Osudu u konce. Ale opak je pravdou - Osud ve vinohradském divadle opět nastudován nebyl. V listopadu 1912 Janáčka informuje Vojtěch Ševčík, že s nastudováním se zatím nezačalo, ${ }^{130}$ ale že má být $O s u d$ další premiérou po Piskáčkově operetě Osudný manévr, která měla premiéru 30. listopadu 1912. Avšak v lednu 1913 sděluje, že zkoušky stále nezačaly; ${ }^{131}$ o měsíc později dokonce upozorňuje na fakt, že party dosud ani nebyly rozdány sólistům. ${ }^{132} \mathrm{O}$ potížích s nastudováním Janáčka informoval 4. února 1913 i Štech a předjednal si s ním schůzku, ${ }^{133}$ která se konala 4 . března v Brně. Dramatik Štech, který sám nebyl hudebně vzdělán, dal na mínění kapelníka Bedřicha Holečka, že je dílo po stránce provozní i umělecké natolik náročné a navíc širšímu publiku nepřístupné, ${ }^{134}$ a že se nehodí do něj investovat. Při brněnské schůzce však Štech patrně poznal Janáčkovu neoblomnost, a proto musel vymyslet opravdu závažný důvod, který by umožnil odstoupení od smlouvy. A tak byla 6 . března 1913 svolaná schůze, jejímž předmětem bylo „opětné zjištěni přičin, pro které nebylo možno na scénu Městského divadla Král. Vinohradi̊ operu , Osud 'od L. Janáčka uvést. " ${ }^{\text {"135 }} \mathrm{V}$ protokolu se uvádí: „Prvni kapelník p. B. Holeček opakuje, což byl dřive již rediteli oznámil, že opera, Osud ' nemůže být nastudována, ježto při rozdání partií vyšlo najevo, že opera ta má takové nesnadné ćásti, že naši pěvci nemohou v ni dostáti úkolům, jež na ně toto dílo klade. Pěvci sami sdělili p. kapelníku Holečkovi, že žádaji, aby roli těch byli zproštěni, poněvadž by poškodili své hlasové prostředky,

\footnotetext{
126 Dopis je uložen v JA MZM, sign. D711.

127 Dopis je uložen v NLJ, sine sign.

128 Dopis je uložen v NLJ, sine sign.

129 Dopis je uložen v JA MZM, sign. D 708.

130 Dopis je uložen v JA MZM, sign. A 441.

131 Dopis je uložen v JA MZM, sign. A 447.

132 Dopis je uložen v JA MZM, sign. A 444.

133 Dopis je uložen v JA MZM, sign. A 3443.

134 Vyjádření Bedřich Holečka je uložené v NLJ, sine sign.

135 Protokol z 6. 3. 1913 je uložen v NLJ, sine sign.
} 
kdyby měli přidělené party zpivati. Tím by po př́padě i zničili se hmotně ve své existenci. “136 Protokol potvrdilo podpisem devět sólistů. O pravém důvodu neuvedení Osudu lépe vypovídá Ševčíkův dopis patrně také z března 1913: „Vedlo by to daleko, kdybych Vám to cele ,proč 'měl vysvětlovati, proto Vám to povím jen několika řádky. Holečekse vyjádřil, že dokud on zde bude kapelnikem, tak že se Váš ,Osud' nebude dávati, udal-li snad osobni pohnutky, to jsem nevyzvédèl. Já jsem ale přesvědčen že on se toho bojí, poněvadž je velký rozdill, naštudovat dílo nové, nikde nedávané, nežli dílo jiné, které se již dávalo a které se může jak se ř́ká obkouknouti. - To je jedno proč. Druhé proč, je, že se o dile mluvi veřejně, že to nic není a podobné a dělá se již predem nálada proti, tak si müžete mysleti s jakou nechutí se sily dílu věnuji a i v obecenstvu se o tom mluví, tak ty lidi jdou již potom do divadla, stím vsugerovaným přesvédčením, že to dílo se musí odsouditi, vlastně odmítnouti. - A potom jsou zde naše lidi velice málo národně vyspěli, aby si českého člověka tak vážili jak by zasluhoval, co zde nemá německý ,punc ‘ tak je to zde nemožné. - To je jak u nás tak i v Národním a němčina je jim přece ještě něco lepšiho. - Já na Vašem mistě bych nestál na rozhodném provedení a za všech okolnosti, ale počkal bych až prijde někdo jiný, kdo by se dílu věnoval s láskou, a kdo by predem na dílo nenadával." "137

Štech, který tušil komplikace, se pokusil ještě celou situaci vyřešit tím, že požádal o nastudování jiného kapelníka, Rudolfa Piskáčka. ${ }^{138} \mathrm{~S}$ tímto řešením nebyl Janáček př́lilš spokojen. ${ }^{139}$ Nicméně ani Piskáček se patrně do nastudování Osudu nehrnul. A tak 5. dubna brněnský advokát Dr. František Pauk Janáčkovi oznámil, že Osud ve vinohradském divadle stáhli z programu a dotázal se, zda má podat žalobu. ${ }^{140}$ Další den dostal Janáček dopis od Rektoryse, který mu zprávu potvrdil: „[...] odkládal jsem, abych nebyl první, který Vám tak nepřijemnou zprávu musí podati. Nyní, když ji již vite, mohu tedy jen rekapitulovati, že ke studiu ,Osudu“ vůbec nedojde, poněvadž členstvo Vin. divadla prohlásilo, že je vůbec nemožno ony partie nastudovati a řid. Štech dal si-očekávaje proces - ona prohlášení solistů protokolovati. Lituji, že Vám nemohu podati zprávy př́jemnějši a bud'te ujištěn, že v této chvíli s Vámi opravdově citím. Dojdeli ke sporu - Štech mi řikal, že obdrželi od Vašeho advokáta již připis - nemohu Vám nežli raditi, abyste byl ve volbě svých znalců - dưvěrníků velmi opatrný. Myslím, že Vy budete asi pomýšlet bud' na Káana neb Čelanského. Tohoto nemohl bych Vám raditi vzhledem kjeho býv. poméru k Vinohr. divadlu, onen jest pak zase př́liš strnulá pagoda, ač jeho úsudek o proveditelnosti by měl ovšem v procesu váhu. Račte mi své event. př́ní bez obav oznámiti, posloužím Vám kde a jak bude v mé moci. “141

136 Zápis je uložen v NLJ, sine sign.

137 Dopis je uložen v JA MZM, sign. A 450.

138 Dopis Václava Štecha Leoši Janáčkovi z 22. 3. 1913 je uložen v JA MZM, sign. D796.

139 Dopis Leoše Janáčka Artuši Rektrysovi z 26. 3. 1913 je uložen v JA MZM, sign. B 1517. Viz též: JA 4, op. cit., s. 153-154.

140 Dopis je uložen v JA MZM, sign. D 705.

141 Dopis je uložen v JA MZM, sign. B 1014. Viz též: JA 4, op. cit., s. 155. 
Janáček zprvu o žalobě přesvědčen nebyl, jak vysvítá z jeho odpovědi Rektorysovi: „Promiňte, že jsem se Vám ani nepoděkoval dosud. Vite, jsem v takové náladě - tři léta práci skládám - pèt leži v divadle, smlouvou se mi zavazuji k provedení--Co udělám, ještě nevím. Nebude-li jistota usvědčit solisty z nepoctivosti jejich povolání, do sporu se nepustím, nebot' ku všemu ještě útraty platit, které mohou prijit do výše 1000 - $2000 \mathrm{~K}$ to prece bylo by přes př́lišs. A na dobrozdáni ,znalcư 'věc sázet, to ne. To má jen príchut’ osobní-poučovat v takové věci se nedám - nikým." 142

Žaloba ale nakonec byla přeci jen 24. května 1913 podána k C. k. zemskému soudu v Praze o náhradu škody ve výši $3000 \mathrm{~K}$. Rozhořel se soudní spor, kde žalovaná strana používala některé značně nečestné postupy (např. svědectví Janáčkova žáka Ladislava Kožušníčka, který sháněl pro žalovanou stranu svědectví o odporu brněnských pěvců k Janáčkovu dílu). Přesto bylo nabíledni, že se kauza nevyvijí pro žalovanou stranu dobře. Navíc celý př́pad budil zájem tisku, který o sporu informoval. ${ }^{143}$ Do kauzy se také zapojil Čelanský, který se právě vrátil na post šéfa opery vinohradského divadla. Ten Janáčka v srpnu 1913 přemlouval, aby žalobu stáhnul s tím, že udělá všechno pro to, aby Osud sám v divadle nastudoval. ${ }^{144}$ Mezitím Janáček na cestě z Karlových Varů onemocněl růží a byl hospitalizován v roudnické nemocnici. I tam Čelanský skladatele prosil o stažení žaloby bez podmínky, že dílo musí nastudovat ihned v nové sezoně. Radí mu Osud zadat znovu, přičemž dosavadní výlohy divadlo uhradí. ${ }^{145}$ Janáček unavený celým sporem souhlasil a 25. záŕí 1913 podepsal ujednání, v němž se zavazuje stáhnout žalobu s tím, že divadlo uhradí vydání do $250 \mathrm{~K}$ a nastuduje Osud v nejbližším vhodném čase. Zde Janáček doplnil: „nejdéle však do tři let ${ }^{\star 1}{ }^{146}$ Žaloba byla Janáčkem vzata zpět 3. listopadu 1913. ${ }^{147}$ Absurdní dohrou je opětovná žaloba, kterou Janáček na vinohradské divadlo (respektive Spojené družstvo Národního divadla v Praze, které vinohradské divadlo provozovalo) znovu podal 28. listopadu 1913 kvůli neuhrazení smluvené částky $250 \mathrm{~K}$. Divadlo totiž tvrdilo, že uhrazení nákladů se týká obou stran (tedy každá strana zaplatí $125 \mathrm{~K}$ ). Soud rozhodl 14. ledna 1914 ve prospěch Janáčka a vinohradské divadlo muselo žalující straně zaplatit $250 \mathrm{~K}$ spolu s částkou $137 \mathrm{~K} 80$ h za výlohy nového řízení. Janáček už nechtěl mít s Městským divadlem na Královských Vinohradech nic společného a tak 28. února 1914 požádal o vrácení partitur, které divadlo zaslalo

142 Dopis 14. 4. 1913je uložen v JA MZM, sign. B 1518. Viz též: JA 4, op. cit., s. 156.

143 REKTORYS, Artuš. Př́ípad Leoše Janáčka. České slovo, 17. 6. 1913 (citováno z Janáčkových výstřižků). Anonymus: U dirigenta Vítězslava Čelanského. O Janáčkově opeře Osud, o krisi divadla vinohradského a o Paříži. Národní obzor, 27. 6. 1913 (citováno z Janáčkových výstřrižků).

144 Dopis je uložen v JA MZM, sign. A 3933.

145 Dopis z 26. 8. 1913 je uložen v JA MZM, sign. B 1013.

146 Úřední listina je uložena v NLJ, sine sign.

147 Úřední listina je uložena v NLJ, sine sign. 
2. března 1914 s poznámkou, že tento akt chápe tak, že Janáček již provedení Osudu nevyžaduje. ${ }^{148}$

\section{Poslední naděje - poslední verze opery}

Energický Janáček chtěl ihned právně uvolněné dílo využít. Zajímavé je, že verze, kterou skladatel odevzdal v listopadu 1907 vinohradskému divadlu, se liš́i od verze finální. Přitom dle pramenů partitury celou dobu ležely v divadle. Je tedy zřejmé, že když Janáček počátkem března 1914 partitury získal zpět, musel do nich provést další změny. Tou nejpodstatnějšś je přepracování úvodní scény 3. jednání. Tu sice ponechává po orchestrální stránce beze změn, ale významně zasáhl do zpěvních hlasů. Částečně se vrátil $\mathrm{k}$ předchozí podobě, kdy začíná zkouška na konzervatoři před zavřenou oponou. Vyškrabal téměř všechny výstupy Kosinské a Vervy, kteří zasahují připomínkami do zkoušky nové opery, a nechává zde pouze sbor. V závěru scény za zavřenou oponou nechá zaznít místo Hrázdy sborové tenorové sólo. Ruší též údiv elevů nad „divným“ koncem opery. Tyto rozsáhlejš́ změny jsou v partituře opět zaznamenány kopistou Svozilem. Provedl také několik drobnějších korekcí, včetně zrušení několika krátkých úseků v 1. jednání a vyškrtnutí závěrečného komentáře Konečného, Lhotského a Sudy Luhačovský román $\mathrm{v}$ témže dějství. To, že závěrečnou revizi provedl Janáček bezprostředně po přijetí partitur z Prahy, potvrzuje i Janáčkův návrh z 16. března 1914 učiněný směrem k České filharmonii, kde nabízí k provedení vedle Šumařova dítěte také předehru ke 3. jednání Osudu. ${ }^{149}$ Dr. Vilém Zemánek, dirigent České filharmonie, obratem nabídku s radostí přijal, přičemž skladby chtěl zařadit hned do nové koncertní sezóny. Stanovil si ale podmínku, že díla bude dirigovat sám Janáček, který si předem určí dostatečný počet zkoušek (krátce předtím totiž mělo dojít na koncertě České filharmonie pod Janáčkovou taktovkou k premiéře skladby Šumařovo ditě, ale pro nedostatečný počet zkoušek Janáček od provedení ustoupil). ${ }^{150} \mathrm{~V}$ dopise z 18 . března skladatel upozorňuje Zemánka, že v předehře ke 3. jednání účinkuje také mužský sbor za scénou. O nastudování požádal Pěvecké sdružení pražských učitelů. ${ }^{151}$ Partituru si však od Františka Spilky, sbormistra pražských učitelů, vyzvedl v květnu 1914 Jaroslav Křička, sbormistr pražského Hlaholu. ${ }^{152}$ Zde stopa po provedení části Osudu Českou filharmonií končí. Na koncertu se neobjevila ani v proklamované sezóně 1914/15 ani v dalších sezónách.

Nejasné je i to, zda Janáček Osud znovu nabídl k provedení brněnskému Národnímu divadlu, jak by mohl napovídat dopis Karla Komarova z 3. července

148 Dopis je uložen v JA MZM, sign. D 713.

149 Zemánkova odpověd' je uložena v JA MZM, sign. D 686-687.

150 Tamtéž.

151 Dopis je uložen v JA MZM, sign. B 753.

152 Dopis Františka Spilky Leoši Janáčkovi z 25. 5. 1914 je uložen v JA MZM, sign. B 125. 
1914: „Dohodli jsme se zatím s řed. Lacinou o mém návratu do Brna na operní režii, a tak budu mit čest, scenovat prvně Váš Osud, jímž Jste ráčil pro letošek brněnské divadlo poctit. "“53 Mohlo však jít od Komarova o pouhou zdvořilost v souvislosti se skladatelovým životním jubileem.

Je jisté, že Janáček si nadále nebyl jistý kvalitou libreta Osudu a proto je dával svým přátelům k posouzení. Novou verzi libreta opsal a zaslal Marii Calmě Veselé, ${ }^{154}$ která se s manželem MUDr. Františkem Veselým přestěhovala v roce 1915 do lázní v Bohdanči. To je také rok, kdy Janáček udržoval s manžely Veselými intenzivní přátelské vztahy a je tedy pravděpodobné, že Marie Calma dostala libreto $\mathrm{k}$ posouzení právě v té době. Co skladateli sdělila nevíme, avšak později vzpomíná, že „,pro naprosto pochybné básnické a dramatické hodnoty libreta sotva kdy dojde k provedeni této Janáčkovy opery“ ${ }^{155}$ Ve vrcholících př́pravách na pražskou premiéru Jeji pastorkyně oznamuje Janáček 14. května 1916 své choti, že po rozhovoru s Františkem Serafinským Procházkou libreto Osudu přehlédne František Langer, ${ }^{156}$ ale ke kontaktu patrně vůbec nedošlo. O půl roku později 9. ledna 1917 pak požádal Janáček o pomoc s libretem samotného Procházku: „Napsal byste mi veršem pěknou romanci na všedni themu? Všedni??"157 Z Procházkovy reakce, kde vysvětluje složitost takové práce, je zřejmé, že se mu do přepracování Osudu vůbec nechtělo. ${ }^{158}$ Skladatel sice prosil, že by rád „,dal Osud operu do čistoty; už mi v tom pomozte“ “, ${ }^{159}$ Procházka se ale k otázce Osudu už nevrátil. O pomoc pro změnu požádal zkušeného dramatika Jaroslava Kvapila, ale ani ten si nevěděl rady, co si s již zhudebněným textem počít. V odpovědi z 26. března 1917 píše: „Ptáte se mne, lze-li nějakým zpưsobem Vaše libreto upraviti, aby bylo divadelně účinnější, arci hudba už je napsána - av té věci je bohužel těžko poradit, a sám bych toho ani nedovedl, nebot' Vaše hudba vzniká přspř́liš ze zvuku i souvislosti jednotlivých slov a jejich smyslu, aby se dala tato slova a tato souvislost nahraditi čímkoli jiným, leda byste se odhodlal na změněný text komponovati znovu. Z libreta samého bylo by lze pro divadlo opravdu užiti jen syrového námětu a ten teprve docela znovu uzpůsobiti dějově i scénicky. Ale to znamená psáti operu novou - a o tuto radu jste mne jistě nežádal! Což tedy? Je mi líto, vážený a vzácný mistře, že Vám nedovedu odpovéděti líp, ale chtěl jste si poslechnouti zkušeného divadelníka - a ten Vám povídá, že tak, jak jest, nelze

153 Dopis je uložen v JA MZM, sign. A 3696.

154 Rukopisné libreto je uloženo v JA MZM, sign. L13.

155 Názor Marie Calmy Veselé je uveřejněn v: REKTORYS, Artuš - RACEK, Jan (eds.). Korespondence Leoše Janáčka s Marii Calmou a MUDr. Františkem Veselým. Praha: Hudební nakladatelství Orbis, 1951, s. 34, Janáčkův archiv 7.

156 Dopis je uložen v JA MZM, sign. D 1217. Viz též: Přibáňová, op. cit., č. 361.

157 Dopis je uložen v JA MZM, sign. B2589. Viz též: REKTORYS, Artuš (ed.). Korespondence Leoše Janáčka s F. S. Procházkou. Praha: Hudební matice Umělecké besedy, 1949, s. 23. Janáčkův archiv 3 (dále JA 3)

Dopis ze 17. 1. 1917 je uložen v JA MZM, sign. B 2590. Viz též: JA 3, op. cit., s. 26. 
Vaše libreto s úspěchem na scénu uvésti. Leda by hudba sama všechny ty nesnáze zmohla tolik, že by na ději a jeho faktuře nezáleželo... Ale pak musí promluviti už jen hudebník, a ne divadelní praktik mého druhu!"160

Poslední z řady literátů, kteří se vyslovili ke kvalitě libreta Osudu, byl Max Brod. Ten o klavírní výtah požádal z vlastního zájmu 3. července $1918,{ }^{161}$ a Janáček mu jej zaslal 28. srpna $1918 .{ }^{162}$ Brod celou operu prostudoval a sdělil autorovi zdrcující názor: „Jen zázrakem a geniální inspiraci by mohl tak nemožný děj ziskat nějakého obsahového smyslu. "163 Tím v podstatě končí Janáčkủv zájem o jeho v pořadí čtvrtou operu. Patrně si naplno uvědomil problematičnost textu a nemožnost jeho úpravy. Proto také později, ačkoliv byl připraven provozovací matriál, uvedení opery neprosazoval, na rozdíl od intenzivní snahy o provedení své dosud nehrané první opery Šárka. Osud se tak stal jedinou skladatelovou operou, kterou nikdy neslyšel (nebudeme-li počítat operu $Z$ mrtvého domu). Za zmínku ještě stojí fakt, že v roce 1916 a 1917 si o opeře vyžádala informace dvě nakladatelství - Schott a Drei Masken Verlag, jejich zájem byl ale zcela povrchní.

Uvedení Osudu inicioval až v roce 1934 Janáčkův žák, dirigent Břetislav Bakala, který operu provedl v Československém rozhlase (ukázku z 1. jednání však uvedl v rozhlase již v roce 1930). Týž dirigent stojí i za dalšími provedeními: $\mathrm{v}$ rozhlase $\mathrm{v}$ roce 1938, rozhlasové nahrávky z roku 1948 a koncertního provedení v roce 1954 (opera byla pokaždé hrána ve zkrácené verzi). Na jeviště se Osud dostal až 25. ř́jna $1958 \mathrm{v}$ tehdejším Státním divadle v Brně (péčí dramaturga Václava Noska a dirigenta Františka Jílka) a o den později byl uveden v městském divadle v Stuttgartu.

Opera Osud reprezentuje spolu s Výletem pana Broučka do Měsíce pro Janáčka zajímavé období tvůrčího vývoje od Jeji pastorkyně k autorovým vrcholným hudebnědramatickým dílům. Janáček chtěl v Osudu vytvořit moderní operu (sám termín moderní v souvislosti s Osudem mnohokrát použil). Myšlenka propojení díla s životem autora právě takovým způsobem byla jistě nová a dobově aktuální, ale jazyková stránka a celkové dramaturgické uchopení se dodnes jeví problematické. Na vině je ponejvíce zveršovaný text, který Janáček nechal vypracovat nezkušenou literátku, která nemohla dostatečně zpracovat a usměrňovat Janáčkovu dramaturgickou vizi. Problematický byl i samotný postup práce, kdy se celková koncepce měnila v již zkomponovaném díle. Naproti tomu po hudební stránce je Osud doslova skvostem. Skladatel zde poprvé do hloubky uplatňuje své zkušenosti s psychologickým studiem lidské řeči, stejně jako postupy montáže vrstev, vytváŕí zde polymetrické plochy atd. Samostatnou kapitolu tvoří instrumentace,

160 Dopis je uložen v JA MZM, sign. A 3462.

161 Dopis je uložen v JA MZM, sign. A 4810. Viz též: RACEK, Jan - REKTORYS, Artuš (eds.). Korespondence Leoše Janáčka s Maxem Brodem. Praha: SNKLHU, Praha 1953, s. 49, Janáčkův archiv 9 (dále JA 9). 
kde skladatel využívá krajních poloh nástrojů, kombinací různých způsobů hry u smyčců i užití netradičního instrumentáře jako varhan, klavíru nebo poprvé violu d'amore. Je příznačné, že Janáček po Osudu již modernost v souvislosti se svými operami nedeklaroval a přitom paradoxně vytvořil ta nejprogresivnější díla ve světové operní literatuře první poloviny 20. století. Avšak právě v této opeře musíme hledat kořeny Janáčkovy touhy o nový př́stup k hudebnědramatické tvorbě. Když uvážíme, jaká operní díla vznikala u nás i ve světě na přelomu století, je zřejmé, že Janáček usiloval o vytvoření moderního díla, které by se vymykalo opernímu schématu 19. století. Díla Richarda Strausse éru romantické opery uzavírala, verismus další cestu pro moderní operu nepředstavoval a Schönbergova expresionistická dramata ještě nespatřila světlo světa. Janáček tedy hledal novou cestu postavenou na realismu a psychologii postav, kterou do jisté míry také nalezl.

Studie je součástí kritického vydání opery, které vyjde u nakladatelství Bärenreiter.

Jiří Zahrádka (jiri.zahradka@seznam.cz) je kurátorem janáčkovských sbírek v hudebním oddělení Moravského zemského muzea v Brně a odborným asistentem na Ústavu hudební vědy FF MU v Brně. Zabývá se životem a dílem Leoše Janáčka, je autorem četných kritických edicí (např. Šárky, Osudu, Výletů páně Broučkových, Př́hod lišky Bystroušky či Glagolské mše). Spolupracuje s nakladatelstvími Universal Edition, Editio Janáček, Editio Bärenreiter a Henle Verlag.

\section{ABSTRACT FATE [OSUD], GROUNDBREAKING WORK IN MANY ASPECTS}

During his summer stay in the Luhačovice spa Leoš Janáček met charming Kamila Urválková who on numerous meetings told him her youth love story which attracted his attention. As a young girl she fell in love with Ludvík Vítězslav Čelanský, a composer and conductor, who after their break-up composed the opera Kamilla based on his own libretto. In this opera he portrayed the main character as an immature and reckless person. Kamila Urválková was deeply offended. The opera was successfully performed by the Prague National Theater in 1897. The story became an inspiration for composer's next opera. After his return to Brno Leoš Janáček started pondering upon the composition structure and looking for a suitable work fellow who would write a libretto. Finally he asked his late daughter Olga's friend, Fedora Bartošová, a young teacher. Fedora rhymed Janáček's prosaic text. At first everything proceeded well and the first libretto version had been finished before Christmas, 1903. The whole structure was then however changed greatly and the libretto Janáček used for his composition was not prepared until July 1904. At this time he also ended his cooperation with Fedora Bartošová. We know very little about the composition work itself. Janáček was composing the present first act using the older libretto version from 10 $0^{\text {th }}$ March to $22^{\text {nd }}$ April 1904 and then probably resumed working in the second half of 1904. The autographed composition was presumably finished in mid-1905. A score copy by Josef Štross includes the only date, $14^{\text {th }}$ June 1905 , at the end of the present third act (originally the first act). Since then the copy has been modified many times. After the score copy had been finished, Janáček drew up, perhaps in the second half of 1905, a practice part (a simple short score) which corresponds to the then act structure and text revision. The part was copied successively in 1906 by Hynek Svozil. Janáček was still working on the opera. In June 1906 he finished the score revision and stated the final opera name as Fatum, thus Fate.

On $16^{\text {th }}$ June 1906 the Družstvo committee of the Czech National Theater in Brno claimed its interest in performing the opera and the premiere was planned for March of the next year. How- 
ever, the opera was not performed and the composer followed Artuš Rektorys' advice and assigned the performance to the newly opened Prague City Theater in Královské Vinohrady. The theater authorities accepted it but studying was being constantly postponed. In 1907 Janáček revised the score again and waited for the Prague performance. When the situation did not change, he was determined to put the theater to court. Finally he gave up and on $2^{\text {nd }}$ March 1914 the Prague theater authorities returned the score with the presumption that Janáček did not request the opera performance any longer. Janáček revised the score once more and tried to have at least the introduction to the third act performed at the Czech Philharmonic concert but did not succeed either. Janáček knew well the libretto was problematic and before 1918 he had asked several writers to rework it. After reading the libretto František S. Procházka, Jaroslav Kvapil and Max Brod declined any cooperation. The composer did not urge the opera performance any more. Thus Fate was not radio broadcasted until 1938 and scenic premiered until 1958.

\section{Key words}

Leoš Janáček, opera, Fate, genesis.

\section{Bibliography}

Anonymus. Divadlo. Městské divadlo Král. Vinohradů. Národní listy, roč. 47, č. 236, s. 3.

Anonymus. Divadlo. Městské divadlo Královských Vinohradů. Národní listy, roč. 47, č. 232, s. 4.

Anonymus. U dirigenta Vítězslava Čelanského. O Janáčkově opeře Osud, o krisi divadla vinohradského a o Paříži. Národni obzor, 27. 6. 1913.

BARTOŠ, František. Janáčkovy dopisy dr. Fr. Skácelíkovi. Tempo, 1947-48, roč. 20, s. 245-246.

ČELANSKÝ, Ludvík Vítězslav. Kamilla. Praha: Fr. A. Urbánek, 1897.

DRLÍKOVÁ, Eva. Jak se Janáček stal sousedem - akademikem. SPFFBU, řada H, 2006, č. 41, s. 53-59.

FIRKUŠNÝ, Leoš. Dopisy Leoše Janáčka z archivu Družstva Národního divadla v Brně. In Musikologie I. Praha - Brno: Melantrich - Pazdírek, 1938.

JANÁČEK, Leoš. Moje Luhačovice. Hlídka, 1903, roč. 20, s. 836-844.

JANÁČEK, Leoš. Pohled do života i díla. Uspořádal a vydal Adolf Veselý. Praha: František Borový, 1924.

PŘIBÁŇOVÁ, Svatava (ed.). Thema con variazioni. Leoš Janáček - korespondence s manželkou Zdeňkou a dcerou Olgou. Praha: Editio Bärenreiter Praha, 2007.

PROCHÁZKOVÁ, Jarmila. Janáčkovy Luhačovice - genius loci at genius musicae. Prameny, Luhačovice, 2009.

RACEK, Jan - REKTORYS, Artuš (eds.). Korespondence Leoše Janáčka s Maxem Brodem. Praha: SNKLHU, Praha 1953.

REKTORYS, Artuš - RACEK, Jan (eds.). Korespondence Leoše Janáčka s Marii Calmou a MUDr. Františkem Veselým. Praha: Hudební nakladatelství Orbis, 1951.

REKTORYS, Artuš (ed.). Korespondence Leoše Janáčka s Artušem Rektorysem. Praha: Hudební matice Umělecké besedy, 1949.

REKTORYS, Artuš (ed.). Korespondence Leoše Janáčka s F. S. Procházkou. Praha: Hudební matice Umělecké besedy, 1949.

REKTORYS, Artuš. Př́ípad Leoše Janáčka. České slovo, 17. 6. 1913.

STRAKOVÁ, Theodora. Janáčkova opera Osud. Časopis Moravského zemského muzea, 1956, roč. 41, s. 209-260.

STRAKOVÁ, Theodora. Janáčkova opera Osud. Část druhá: Libreto. Látka a tvar. Časopis moravského muzea, 1957, roč. 42, s. 133-140.

TRKANOVÁ, Marie. Paměti: Zdeňka Janáčková - můj život. Brno: Nakladatelství Šimon Ryšavý, 1998. 
TYRELL, John. Janáček's Operas. A Documentary account. London: Faber and Faber, 1992.

TYRRELL, John. Janáček. Years of Life. Volume 1 (1854-1914). London: Faber and Faber, 2006.

VESELÝ, Adolf E. Po stopách Dra. Leoše Janáčka. Brno: Brněnské knižní nakladatelství, 1930. 